\title{
Characterization and Source Analysis of Water-soluble Ions in Atmospheric Particles in Jinzhong, China
}

\author{
Ling Mu*, Lirong Zheng, Meisheng Liang*, Mei Tian, Xuemei Li, Danhua Jing \\ College of Environmental Science and Engineering, Taiyuan University of Technology, Taiyuan 030024, China
}

\begin{abstract}
Size-segregated samples $(<2.5,2.5-5,5-10$, and 10-100 $\mu \mathrm{m})$ and $\mathrm{PM}_{2.5}$ samples were collected to analyze the watersoluble inorganic ions (WSIs, including $\mathrm{F}^{-}, \mathrm{Cl}^{-}, \mathrm{NO}_{3}{ }^{-}, \mathrm{SO}_{4}{ }^{2-}, \mathrm{Na}^{+}, \mathrm{NH}_{4}^{+}, \mathrm{K}^{+}, \mathrm{Mg}^{2+}$, and $\mathrm{Ca}^{2+}$ ), through ion chromatography

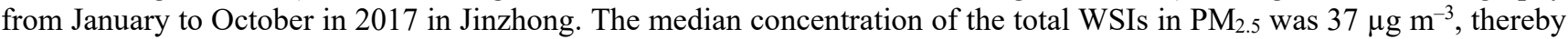
accounting for $31 \%$ of the $\mathrm{PM}_{2.5}$, with the lowest level in spring and the highest in autumn. $\mathrm{SO}_{4}{ }^{2-}, \mathrm{NO}_{3}{ }^{-}$, and $\mathrm{NH}_{4}{ }^{+}$were the most abundant substances and were primarily on the fine particles $(0-2.5 \mu \mathrm{m})$, whereas $\mathrm{Ca}^{2+}, \mathrm{Mg}^{2+}$, and $\mathrm{F}^{-}$were concentrated on the coarse particles $(2.5-100 \mu \mathrm{m})$. The results of the correlation analysis led to the conclusions that $\left(\mathrm{NH}_{4}\right)_{2} \mathrm{SO}_{4}, \mathrm{NH}_{4} \mathrm{Cl}$ and $\mathrm{K}_{2} \mathrm{SO}_{4}$ were the primary compounds on the fine particles, $\mathrm{MgSO}_{4}$ and $\mathrm{CaSO}_{4}$ were the major chemical forms of WSIs on the coarse particles, thus indicating that the formation mechanisms of these compounds were different; however, $\mathrm{NH}_{4} \mathrm{NO}_{3}$ and $\mathrm{KNO}_{3}$ were present in both the types of particles. The particles that were observed in Jinzhong were alkaline during the study period, and their acidity was negligible. The ratio analysis showed that the highest ratio of $\mathrm{Cl}^{-} / \mathrm{K}^{+}$was found in winter in both fine and coarse particles; however, no obvious distinction has been made between $\mathrm{Mg}^{2+} / \mathrm{Ca}^{2+}$ during the four seasons. The $\mathrm{NO}_{3}{ }^{-} / \mathrm{SO}_{4}{ }^{2-}$ ratio in coarse particles was observed to be significantly higher than that in fine particles, particularly in summer, thus indicating that the heterogeneous reaction on particles plays a vital role in the formation of $\mathrm{NO}_{3}{ }^{-}$in coarse particles. The PCA analysis showed that the primary factors of WSIs, which were secondary formation, coal combustion, biomass burning, dust particles, and industrial emission. The coal combustion and biomass burning have been considered as the leading emission sources to be controlled for improving air quality in Jinzhong.
\end{abstract}

Keywords: Fine particles; Coarse particles; WSIs; Size distribution; Source factors.

\section{INTRODUCTION}

Over the past few years, China has faced severe air pollution. The 24-hour $\mathrm{PM}_{2.5}$ in many cities has exceeded the limit of National Ambient Air Quality Standards (NAAQS) in China (Zhang et al., 2011; Xu et al., 2014; He et al., 2017). Water-soluble inorganic ions (WSIs) were the primary chemical constituent of PM, accounting for approximately $23 \%-82 \%$ of the mass of the fine particles concentration in Beijing, in which $\mathrm{SO}_{4}{ }^{2-}, \mathrm{NO}_{3}{ }^{-}$, and $\mathrm{NH}_{4}{ }^{+}$contributed more than $30 \%$ of the fine particles (Particles diameter of 2.1 microns or less was presented as the fine particles) (Liu et $a l ., 2017)$. WSIs not only affect the atmospheric precipitation and particle $\mathrm{pH}$ and increase the frequency of acid rain, but also exacerbate impairment on visibility and human health (Osunsanya et al., 2001). For example, sulfate is the main

\footnotetext{
* Corresponding author.

Tel.: +86 3516010152; Fax: +86 3516010152

E-mail address: lingm_tyut@163.com (M. Liang); muling@tyut.edu.cn (L. Mu)
}

species that affects light scattering and visibility and the average contribution to the light scattering coefficient is $40 \%$ for sulfate and $16 \%$ for nitrate (Tao et al., 2009). The smaller the aerosol particles size, the greater the harm to human health (de Kok et al., 2009) and ultrafine particles easily enter the human body's bronchi to damage the respiratory tract and cause alveolar inflammation, which largely increases the incidence of cardiopulmonary disease and lung cancer (Osunsanya et al., 2001).

Based on the significant hazards of WSIs in the environment and human beings, systematic research about their distribution characteristics and source apportionment is necessary. Studies have shown that the concentration ratio of nitrate and sulfate can indicate the contribution of stationary (e.g., coal) and mobile sources (e.g., motor vehicles) to sulfur and nitrogen in the atmosphere (Huebert et al., 1988). High $\mathrm{Cl}^{-}$concentrations are often associated with coal combustion (Yao et al., 2003). Many studies have examined the WSIs of atmospheric PM in urban areas in China, e.g., Beijing (Wang et al., 2005; Liu et al., 2017), Guangzhou (Xia et al., 2017), Tianjin (Wang et al., 2016a), Nanjing (Yu et al., 2016).

Shanxi is a heavily industrial region in the northern region 
of China, which partakes in substantial coal consumption for energy production and industrial activities, including electricity, coke, steel, and chemical products. Shanxi ranked third $(10 \%)$ on the list of cities in China in terms of $\mathrm{PM}_{2.5}$ $\left(\mathrm{PM}_{2.5}\right.$ refers to suspended particles with a dynamic diameter of 25 microns or less in ambient air.) concentration peaks (the daily $\mathrm{PM}_{2.5}$ maximum concentrations), followed by Hebei (44\%) and Beijing (31\%) (Zhai et al., 2018). Meng et al. (2007) noted that the average daily $\mathrm{PM}_{2.5}$ concentration $\left(193 \mu \mathrm{g} \mathrm{m}^{-3}\right)$ in Taiyuan, the provincial capital of Shanxi, exceeded the 24-h US NAAQS $\left(65 \mu \mathrm{g} \mathrm{m}^{-3}\right)$. According to He et al. (2017), the average WSIs concentration in Taiyuan is $69 \mu \mathrm{g} \mathrm{m}^{-3}$, thereby accounting for $33 \%$ of the $\mathrm{PM}_{2.5}$ mass concentration, which is lower than that in Xi'an (39\%) (Zhang et al., 2011) but considerably higher than that in Beijing (29\%) (Wang et al., 2005) and Chengdu (29\%) (Tao et al., 2013). However, few studies have been conducted regarding other cities in Shanxi, with the exception of Taiyuan.

Jinzhong is a city wherein coal combustion occurs; it is located in the northern region of the Taiyuan basin and is connected with Taiyuan in the northwest region. The terrain expanding from northern to southern Taiyuan is known to be similar to a dustpan, thus resulting in limited diffusion channels for air pollution (Meng et al., 2007). The unique geographical location and meteorological conditions (such as wind speed and wind direction) affect the pollution distribution of Jinzhong. Jinzhong is located at the downwind direction and northwest wind prevails in winter. Therefore, it is likely to be polluted by the pollutants from Taiyuan. Information regarding the characterization of WSIs in Jinzhong is considered to be crucial for understanding the formation mechanism and emission sources of air pollutants in this heavily polluted region.

As a vital parameter of PM, particle size significantly alters the nature of the particles and influences the residence time in the atmospheric environment. Particles with small particle size have a longer suspension time in the air and are prone to be adsorbed into the lung, which poses a great hazards to the respiratory system of human. WSIs are the main components of atmospheric aerosols. By studying the size distribution of WSIs, it is helpful to understand the transformation and transport of aerosols, and to explore the formation pathway. Some studies have examined the size distribution of WSIs in the northern cities in China, such as Beijing (Wang et al., 2005; Yang et al., 2015), Jing-Jin-Ji (Li et al., 2013) and Taiyuan (He et al., 2017). However, no relevant studies have investigated the size distribution characteristics of WSIs in Jinzhong.

In this study, $\mathrm{PM}_{2.5}$ and size-segregated samples with varying particle sizes, including $<2.5 \mu \mathrm{m}\left(\mathrm{PM}_{2.5}\right), 2.5-5 \mu \mathrm{m}$ $\left(\mathrm{PM}_{2.5-5}\right), 5-10 \mu \mathrm{m}\left(\mathrm{PM}_{5-10}\right)$, and $10-100 \mu \mathrm{m}\left(\mathrm{PM}_{10-100}\right)$, were collected from Jinzhong. This study has the following research objectives: (1) to obtain the size distribution characteristics, seasonal variations, and chemical form of WSIs and (2) to identify the sources of WSIs in Jinzhong. The results will be beneficial for an improved understanding about PM pollution and for establishing related pollution control measures in China.

\section{EXPERIMENTAL METHODS}

\section{Aerosol Sampling}

The sampling instruments were mounted on the roof of an office building on the campus of the Taiyuan University of Technology, Mingxiang, approximately $12 \mathrm{~m}$ above the ground (Fig. 1). A total of 109 samples, including 64 graded samples, $41 \mathrm{PM}_{2.5}$ samples, and 4 parallel samples were obtained over the course of four seasons. The sampling was conducted at $24 \mathrm{~h}$ intervals for 10 days during each season. The four periods were April 26-May 6 during spring, July 9-18 during summer, October 11-21 during autumn, and January 3 to 13 during winter. Due to the weather conditions, intermittent rain occurred during the sampling period The collected samples during the rainy days account for $15 \%$ of the whole samples in this study (none in winter, $20 \%$ in spring, 30\% in summer and $10 \%$ in autumn during individual season, respectively).

Daily samples were collected on quartz fiber filters ( 75 and $90 \mathrm{~mm}$ ) with two medium-flow air samplers (MH1200-A) at a flow rate of $100 \mathrm{~L} \mathrm{~min}^{-1}$. One of the samplers collected the $\mathrm{PM}_{2.5}$ samples, and the other sampler was used to collect size-segregated samples, including $\mathrm{PM}_{2.5}, \mathrm{PM}_{2.5-5}, \mathrm{PM}_{5-10}$, and $\mathrm{PM}_{10-100}$. The samplers were calibrated and checked using the flow calibrator before each sampling. Sampling basic information and statistics of the meteorological data during the sampling time are shown in Table 1. After being balanced for $72 \mathrm{~h}$ in a dryer, the filters were weighed before and after sampling by using an electronic balance with a reading precision of $0.1 \mathrm{mg}$. Field blank filters were also collected in the sampler during the sampling period, without drawing air. The filters were placed in a filter cartridge after the sampling and were stored at $-20^{\circ} \mathrm{C}$ before the analysis to prevent the evaporation of any volatile components. During the sampling period, meteorological data, including ambient temperature, relative humidity $(\mathrm{RH})$, wind direction, and speed, were obtained for the first 24 hours at 9:00 every day from the China Weather website online (http://www.weather. com.cn/). The supplementary material of meteorological data is shown as Table $\mathrm{S} 1$. In this study, $\mathrm{PM}_{2.5}$ was considered to be fine particles; particles ranging from 2.5 to $100 \mu \mathrm{m}$ were presented as coarse particles.

\section{Chemical Analysis}

The samples were analyzed for WSIs species. Using $10 \mathrm{~mL}$ ultra-pure deionized water in a centrifuge tube for $30 \mathrm{~min}$, $1 / 8$ of the filter was extracted and was then filtered with a $0.45 \mu \mathrm{m}$ Teflon filter to remove any insoluble species. The extracted solutions were transferred to clean plastic bottles and were then stored in the refrigerator. Blank filters were also analyzed using the same method. Four anions $\left(\mathrm{F}^{-}, \mathrm{Cl}^{-}\right.$, $\mathrm{NO}_{3}{ }^{-}$, and $\left.\mathrm{SO}_{4}{ }^{2-}\right)$ and five cations $\left(\mathrm{Na}^{+}, \mathrm{NH}_{4}{ }^{+}, \mathrm{K}^{+}, \mathrm{Mg}^{2+}\right.$, and $\mathrm{Ca}^{2+}$ ) were analyzed using two ion chromatographs (Dionex ICS-90, USA and 861 Advanced Compact IC). The results of the samples for the WSIs were corrected using filter blanks. In order to select more accurate samples for analysis, the samples of four days (sampling for the whole $24 \mathrm{~h}$ ) per season were chosen for the analysis on the coarse particles. 

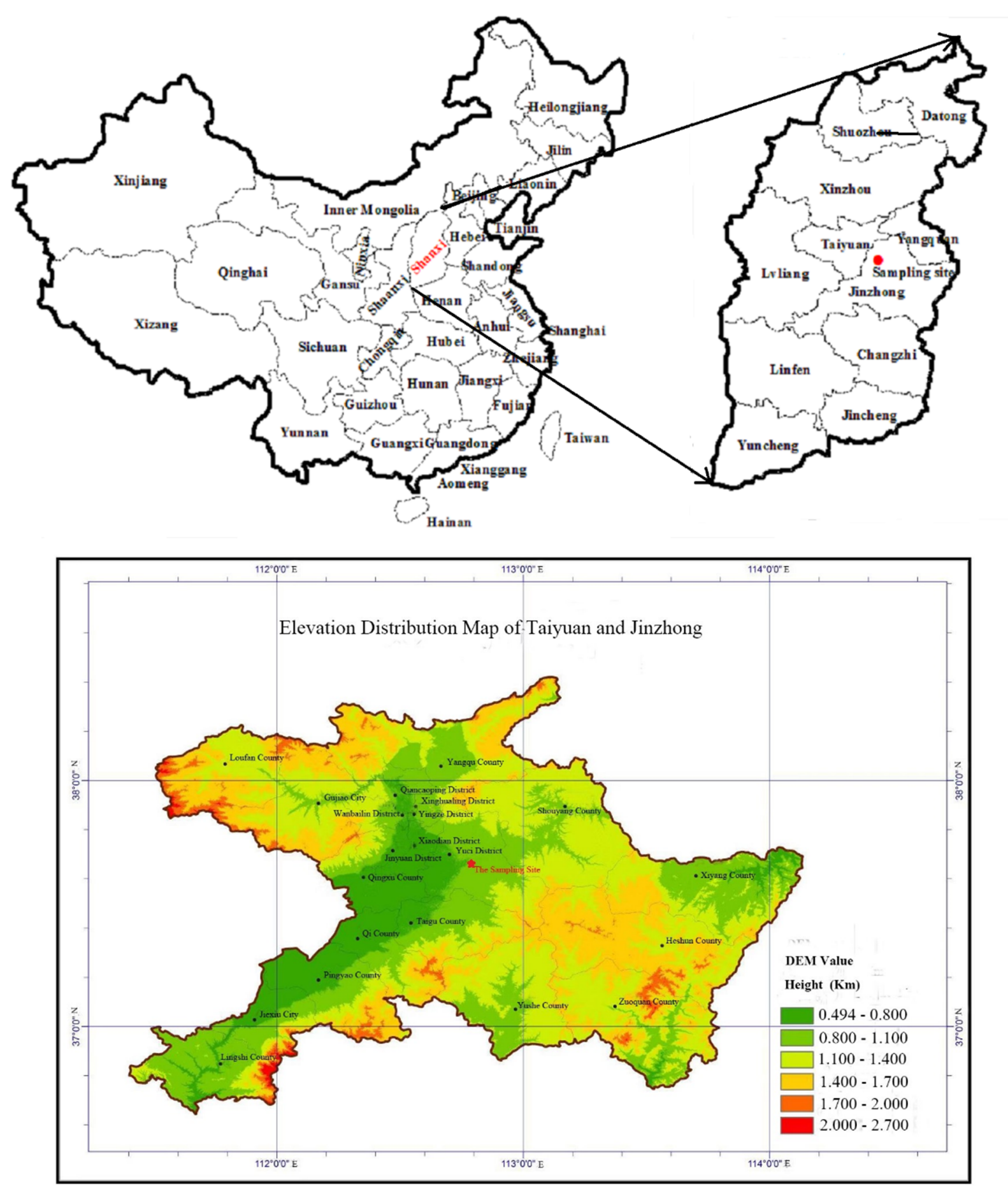

Fig. 1. Sketch of a combined overview map of the study site and DEM (ASTER DEM V2; Resolution: 30 meters).

Table 1. Sampling basic information and statistics of meteorological data during the sampling period.

\begin{tabular}{llllllll}
\hline Season & Sampling period & $\begin{array}{l}\text { Number of } \\
\text { size-segregated } \\
\text { samples }\end{array}$ & $\begin{array}{l}\text { Number } \\
\text { of } \mathrm{PM}_{2.5} \\
\text { samples }\end{array}$ & $\begin{array}{l}\mathrm{T} \\
{ }^{\circ} \mathrm{C}\end{array}$ & $\begin{array}{l}\mathrm{RH} \\
\%\end{array}$ & $\begin{array}{l}\text { Air pressure } \\
\mathrm{kPa}\end{array}$ & $\begin{array}{l}\mathrm{PM}_{2.5} \\
\mu \mathrm{g} \mathrm{m} \mathrm{m}^{-3}\end{array}$ \\
\hline Winter & 3 Jan.-2 Mar. & 16 & 12 & $7(-12$ to 12$)$ & $52(27-82)$ & 101 & $105(25-290)$ \\
Spring & 26 Apr.-6 May & 24 & 11 & $16(4-29)$ & $12(5-27)$ & 102 & $41(18-300)$ \\
Summer & 9 Jul.-18 Jul. & 16 & 11 & $28(19-38)$ & $43(35-66)$ & 100 & $37(19-62)$ \\
Autumn & 11 Oct.-21 Oct. & 16 & 11 & $11(3-19)$ & $88(75-99)$ & 103 & $74(42-120)$ \\
\hline
\end{tabular}




\section{Backward Trajectory Analysis}

The model called Hybrid Single Particle Lagrangian Integrated Trajectory (HYSPLIT), which was developed by the National Oceanic and Atmospheric Administration, was used to preliminarily distinguish the pollution sources of the atmospheric particles (https://ready.arl.noaa.gov/HYSPLIT traj.php). The Global Data Assimilation System database was used as meteorological inputs in this model, and the university town, Shanxi $\left(37.75^{\circ} \mathrm{N}, 112.72^{\circ} \mathrm{E}\right)$, was selected as the starting point. Considering the strong movement of dust aerosols below a height of $1000 \mathrm{~m}$ (Han, 2007), three height levels $(100 \mathrm{~m}, 500 \mathrm{~m}, 100 \mathrm{0m})$ were chosen to investigate the primary transport path and potential source areas in Jinzhong in this study. For each sampling season, a 10-day back trajectory was computed at 16:00 h UTC.

\section{RESULTS AND DISCUSSION}

\section{Size Distribution of PM and WSIs PM Distribution}

During the sampling process, the TSP concentrations ranged from 180 to $293 \mu \mathrm{g} \mathrm{m}^{-3}$, with a median of $219 \mu \mathrm{g} \mathrm{m}^{-3}$, which was slightly lower than that of Xi'an $\left(265 \mu \mathrm{g} \mathrm{m}^{-3}\right)$ (Shen et al., 2009), whereas it was significantly higher than the first-level value of NAAQS $\left(120 \mu \mathrm{g} \mathrm{m}^{-3}\right)$. Fig. 2 shows the size distribution of PM and WSIs. The findings show that $\mathrm{PM}_{2.5}$ was the primary component of the atmospheric particulates, which accounted for $41 \%$ of the TSP, followed by $\mathrm{PM}_{10-100}$,
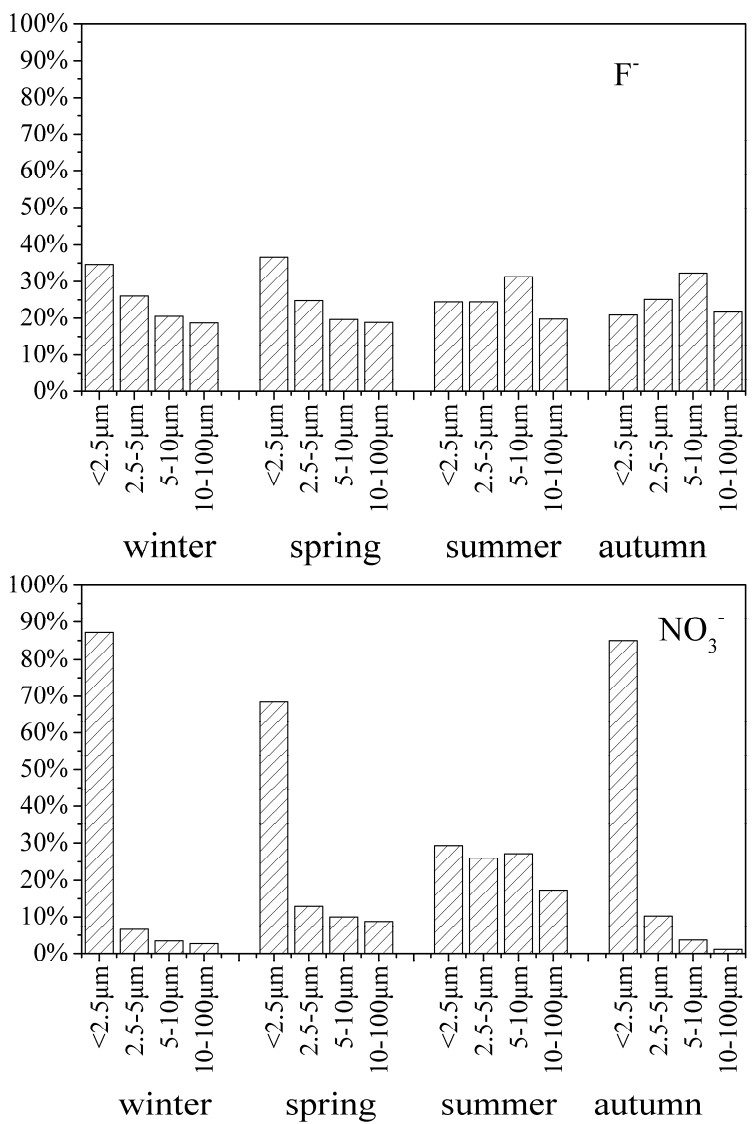

which accounted for $22 \%$. The seasonal variations in $\mathrm{PM}_{2.5}$ were winter $(57 \%)>$ autumn $(44 \%)>$ spring $(39 \%)>$ summer $(33 \%)$, and the highest of $\mathrm{PM}_{2.5}$ concentrations in winter may be related to the increased consumption of coal and the decreased temperature and rainfall compared with the summer (Zhou et al., 1992).

\section{WSIs Distribution}

The mass concentrations of the total WSIs in the TSP ranged from 15 to $139 \mu \mathrm{g} \mathrm{m}^{-3}$, with a median of $39 \mu \mathrm{g} \mathrm{m}^{-3}$, which accounted for $21 \%$ of the TSP, which was lower than that of Xi'an $(33 \%)$. The order of the annual WSIs concentration was $\mathrm{SO}_{4}{ }^{2-}>\mathrm{NO}_{3}{ }^{-}>\mathrm{NH}_{4}{ }^{+}>\mathrm{Ca}^{2+}>\mathrm{Cl}^{-}>\mathrm{K}^{+}>$ $\mathrm{Na}^{+}>\mathrm{Mg}^{2+}>\mathrm{F}^{-}$. The secondary water-soluble inorganic ions (SNAs), including $\mathrm{SO}_{4}{ }^{2-}, \mathrm{NO}_{3}{ }^{-}$, and $\mathrm{NH}_{4}{ }^{+}$, were the most abundantly observed substances, thus accounting for $81 \%$ of the total WSIs. Research has shown that WSOC is one of the main water-solution species of TSP and accounts for about $4 \%$ in Guiyang (Chen, 2010) and 6\% in Nanjing (Wu et al.,2017). Based on this, we can estimate the mass concentration of WSOC to TSP in Jinzhong, ranged from 1 to $8 \mu \mathrm{g} \mathrm{m}^{-3}$.

Fig. 2 shows that the proportion of ions that are distributed in $\mathrm{PM}_{2.5}$ was the highest, thus accounting for $75 \%$ of the total ions in the TSP. The contribution of $\mathrm{Cl}^{-}, \mathrm{NO}_{3}{ }^{-}, \mathrm{SO}_{4}{ }^{2-}, \mathrm{Na}^{+}$, $\mathrm{NH}_{4}{ }^{+}$, and $\mathrm{K}^{+}$in $\mathrm{PM}_{2.5}$ is considerably higher than that of the coarse particles. Kumar et al. (2017) examined the content of WSIs in different sized particles in New Delhi and concluded
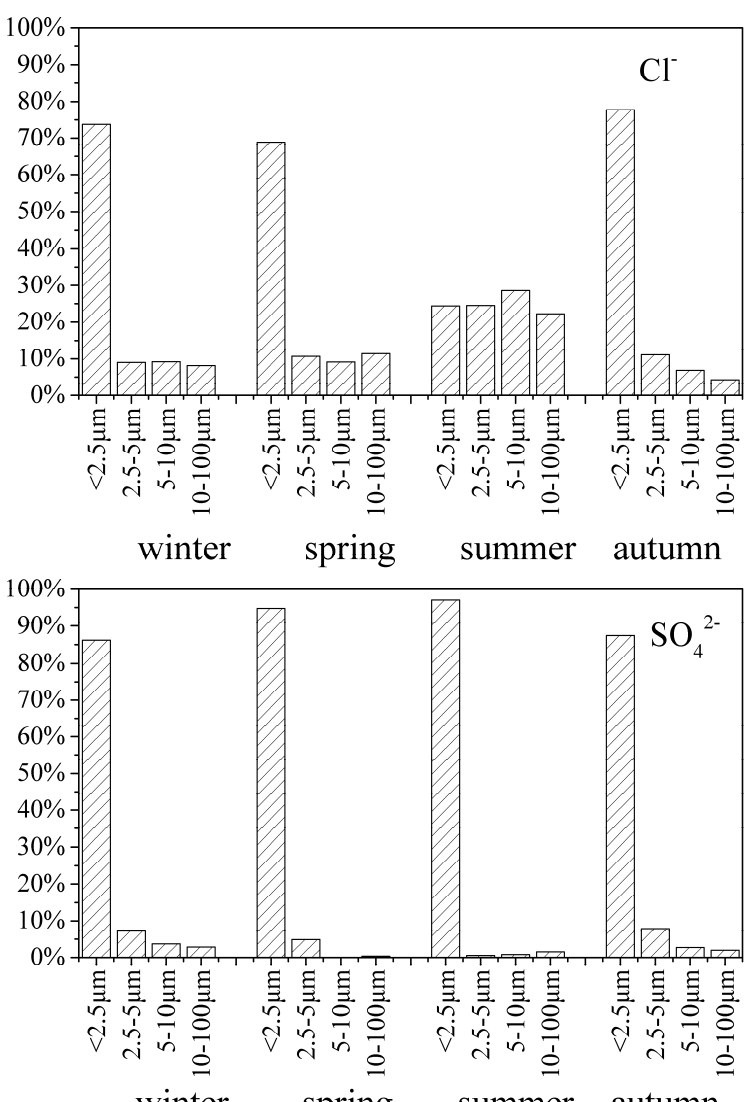

Fig. 2. Size distribution of WSIs and particles. 

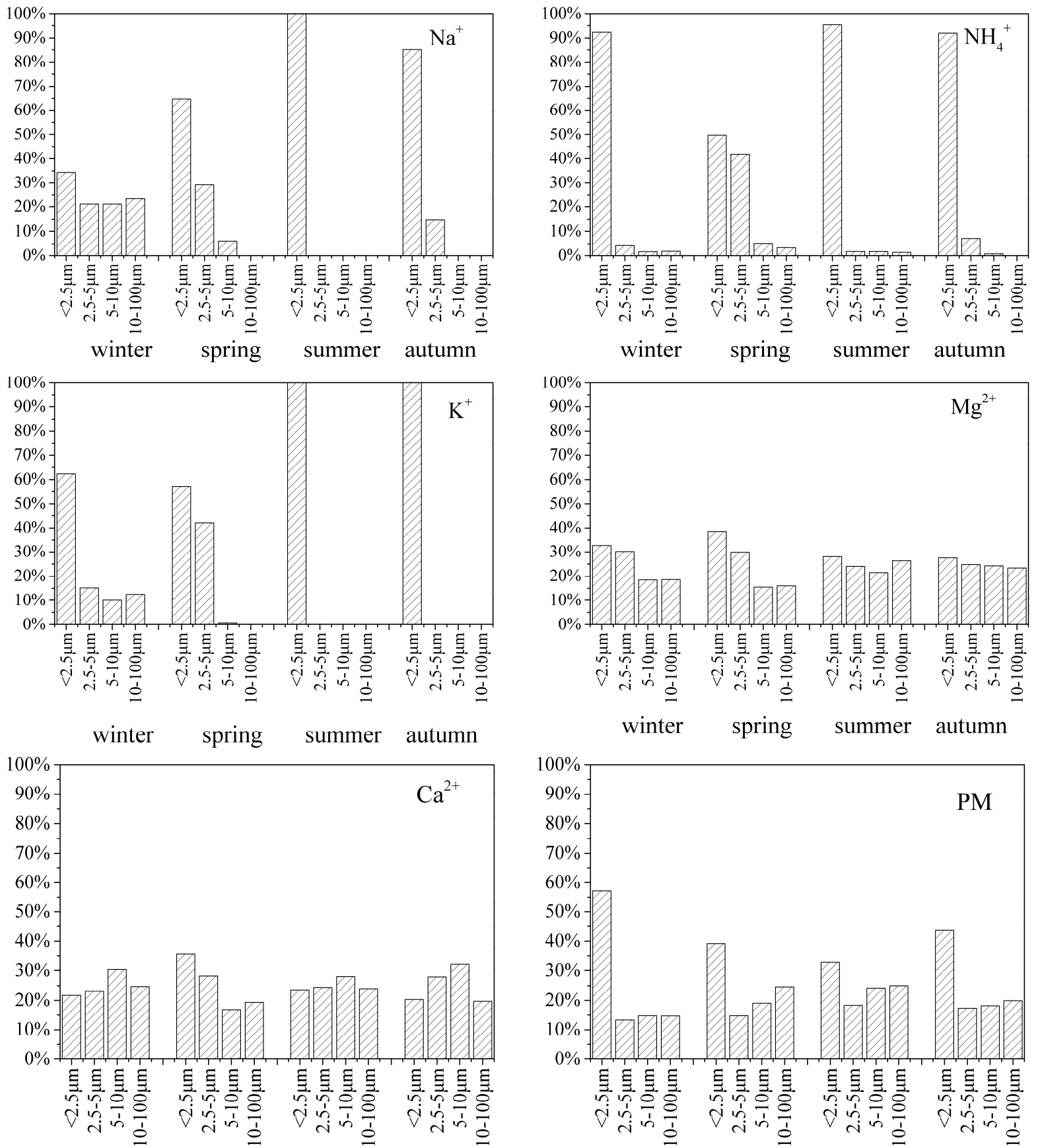

winter spring summer autumn

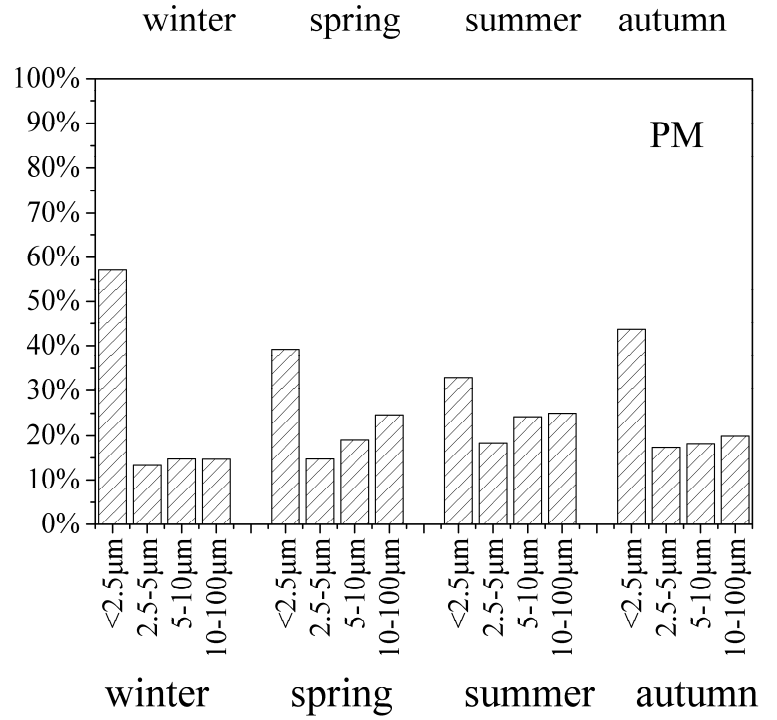

Fig. 2. (continued).

that when the particle size decreases, the contribution of WSIs in the particles increase. Therefore, the results of this study are consistent with those of Kumar et al. (2017).

Compared with other ions, the contribution of $\mathrm{Ca}^{2+}, \mathrm{Mg}^{2+}$, and $\mathrm{F}^{-}$in the coarse particles increased, thereby accounting for $76 \%, 68 \%$, and $69 \%$ of the total WSIs, respectively. Li et al. examined the size distribution of WSIs in Huangshan and their findings also showed that the concentration of $\mathrm{Ca}^{2+}$ increased along with the increase of particle size in $\mathrm{PM}_{100}$ (Li et al., 2014). Re-suspended road dust, soil dust, and construction dust are the primary sources of $\mathrm{Mg}^{2+}$ and $\mathrm{Ca}^{2+}$
(Liu et al., 2017). The increased content of $\mathrm{Ca}^{2+}$ and $\mathrm{Mg}^{2+}$ in the coarse particles obtained in this study may be related to the road and construction dust around the sampling point. The high $\mathrm{F}^{-}$concentration in the coarse particles may be attributed to the soil dust and decomposition of living organisms (Xiu et al., 2004).

\section{Concentrations and Seasonal Variations in PM 2.5 and WSIs $P M_{2.5}$}

Fig. 3 shows the daily $\mathrm{PM}_{2.5}$ concentrations in Jinzhong during the sampling period. The $\mathrm{PM}_{2.5}$ concentrations ranged 
from 45 to $326 \mu \mathrm{g} \mathrm{m}^{-3}$, with a median of $133 \mu \mathrm{g} \mathrm{m}^{-3}$, thereby exceeding the 24-h $\mathrm{PM}_{2.5}$ concentration limitation value of $35 \mu \mathrm{g} \mathrm{m}^{-3}$ in the United States Environmental Protection Agency (US EPA) and $75 \mu \mathrm{g} \mathrm{m}^{-3}$ in Chinese NAAQS. The $\mathrm{PM}_{2.5}$ concentration obtained in this study was higher than that of many domestic cities, such as Tianjin $\left(69 \mu \mathrm{g} \mathrm{m}^{-3}\right)$ (Xing et al., 2017), Lanzhou (77 $\left.\mu \mathrm{g} \mathrm{m}^{-3}\right)$ (Tan et al., 2017), Beijing $\left(107 \mu \mathrm{g} \mathrm{m}^{-3}\right)(\mathrm{Xu}$ et al., 2017b) and some foreign countries, such as Kathmandu (Nepal) $\left(76 \mu \mathrm{g} \mathrm{m}^{-3}\right)$ (Shakya et al., 2017), Verneuil (Central France) $\left(10 \mu \mathrm{g} \mathrm{m}^{-3}\right)(\mathrm{He}$ et $a l ., 2018)$, and Veneto Region (Italy) $\left(24 \mu \mathrm{g} \mathrm{m}^{-3}\right)$ (Khan et al., 2016). These findings may be related to the increased coal combustion in the Shanxi province. Moreover, the sampling point was located in the Taiyuan basin, thereby hindering the diffusion of contaminants.

The $\mathrm{PM}_{2.5}$ concentration was higher in winter $\left(159 \mu \mathrm{g} \mathrm{m}^{-3}\right)$ and spring $\left(187 \mu \mathrm{g} \mathrm{m}^{-3}\right)$ and was lower in autumn $\left(119 \mu \mathrm{g} \mathrm{m}^{-3}\right)$ and summer $\left(91 \mu \mathrm{g} \mathrm{m}^{-3}\right)$. During winter, coal combustion increases because it is used for heating; moreover, the relatively low temperature and wind speed and relatively stable atmospheric conditions in autumn and winter are not suitable for the diffusion of pollutants. By contrast, frequent rainfall was observed to be favorable for the removal of $\mathrm{PM}_{2.5}$ in summer and autumn. A surprising finding is that the $\mathrm{PM}_{2.5}$ concentration in spring was slightly higher than in winter. Zhao et al. (2016) noted that cities in the desert regions of northwestern and west-central China experienced increased pollution in spring compared with winter because of dust storms. During the sampling period from May 3 to May 6, 2017, strong sandstorms occurred in most northern regions in China; specific information regarding the sandstorm can be obtained through the Weather China website (http://www. weather.com.cn/zt/tqzt/2699655.shtml). Therefore, the higher $\mathrm{PM}_{2.5}$ concentration in spring observed in this study may be related to the severe dust storm in spring of 2017.

Fig. 4 shows that the backward trajectory during the collection period arrived at an altitude of $100 \mathrm{~m}, 500 \mathrm{~m}$ and $1000 \mathrm{~m}$ (above ground level) during different seasons. Except for the fall, the air mass trajectories are basically consistent in different heights. Fig. 4(a) reproduce well the typical wind direction during winter in Jinzhong. In summer, the air mass came from southern and eastern cities to the

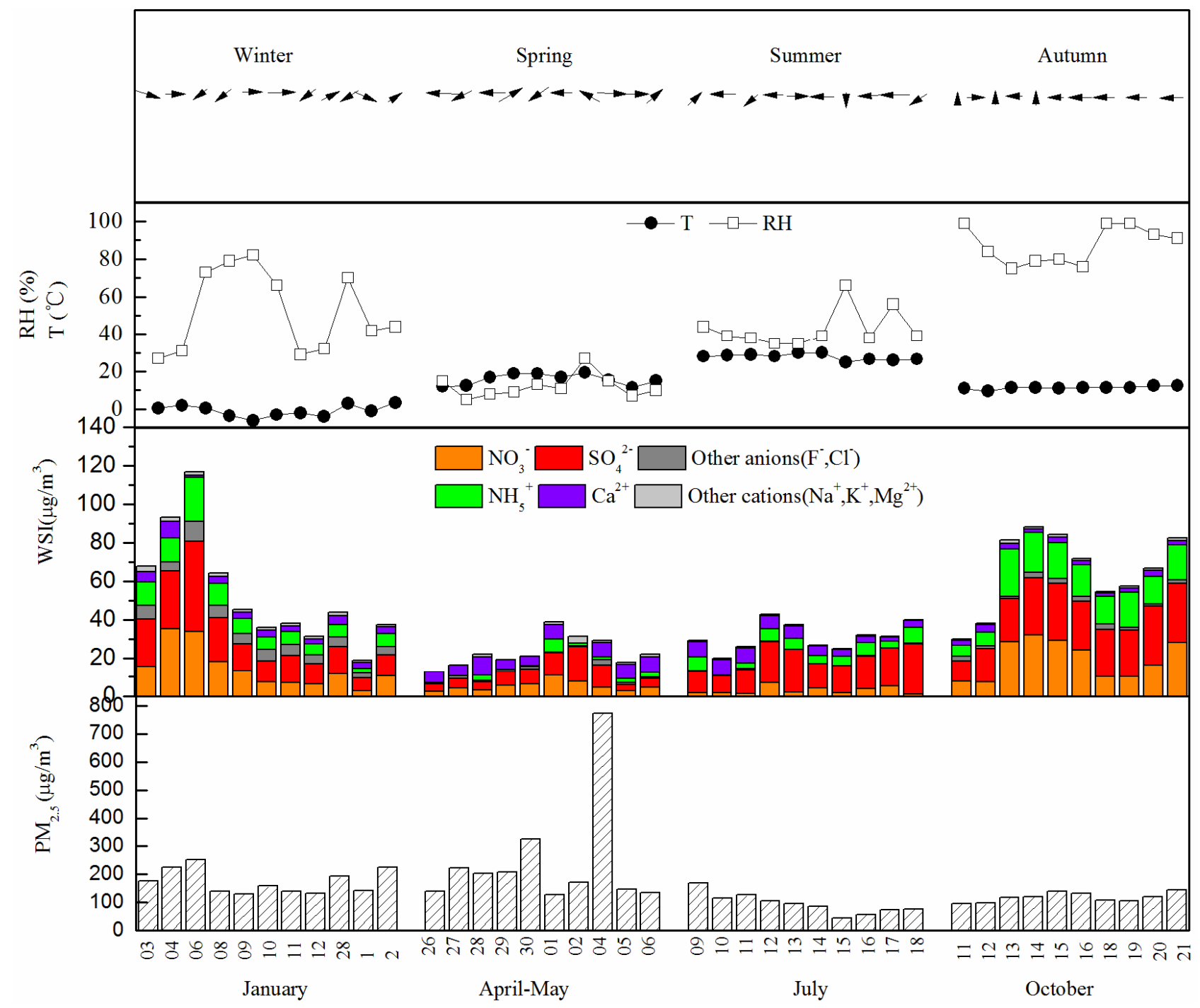

Fig. 3. Distribution characteristics of $\mathrm{PM}_{2.5}$ and WSIs. 


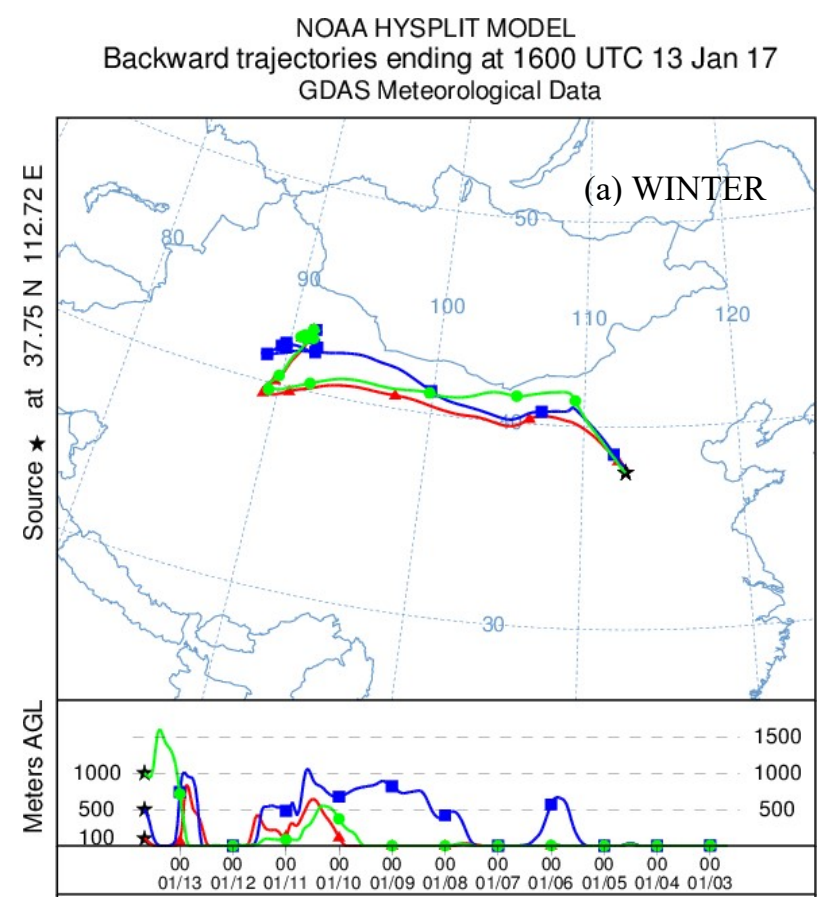

NOAA HYSPLIT MODEL

Backward trajectories ending at 1600 UTC 18 Jul 17 GDAS Meteorological Data

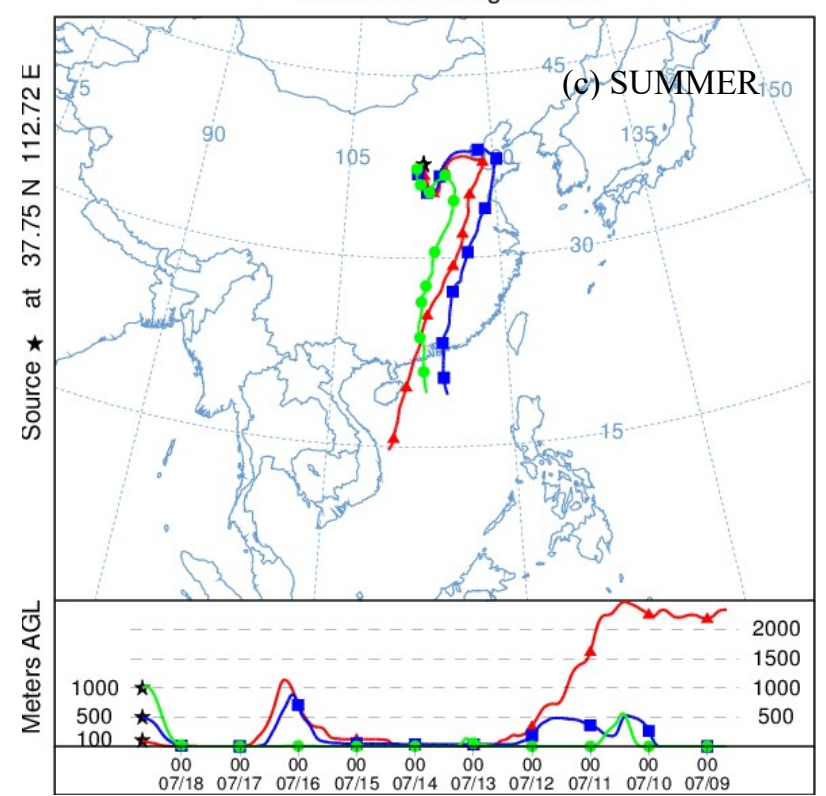

NOAA HYSPLIT MODEL

Backward trajectories ending at 1600 UTC 06 May 17 GDAS Meteorological Data

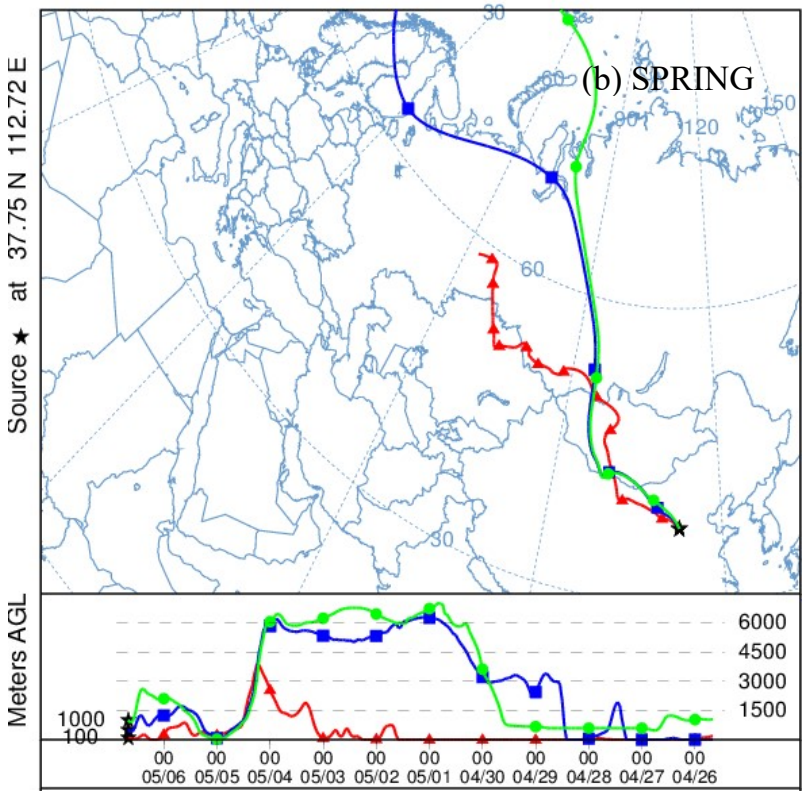

NOAA HYSPLIT MODEL

Backward trajectories ending at 1600 UTC 21 Oct 17 GDAS Meteorological Data

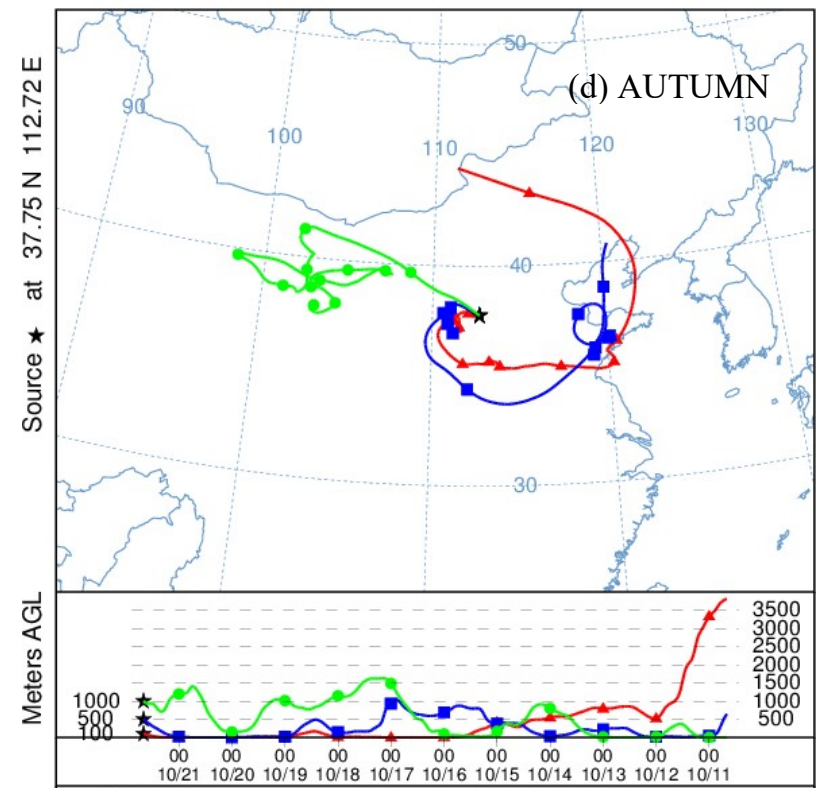

Fig. 4. Seasonal backward trajectory at an altitude of $100 \mathrm{~m}, 500 \mathrm{~m}$ and $1000 \mathrm{~m}$ (above ground level) during the sampling period of 2017 .

sampling site. Fig. 4(b) shows that the air mass in the study area during spring primarily originated from Mongolia and Inner Mongolia, which further demonstrates that the increased $\mathrm{PM}_{2.5}$ concentrations during spring is primarily related to long-distance transportation in Mongolia and Inner Mongolia. Koracin et al. (2011) showed that HYPLIT backward trajectories have a tendency to underestimate sources that are close to the receptor site and to overestimate the effects of the more distant sources. Based on this limitation, it may lead to an overestimation the effects of long-distance transport from Mongolian and Inner Mongolia and an underestimation of the impact of local anthropogenic pollution sources for $\mathrm{PM}_{2.5}$ in Jinzhong in this study. In autumn, air masses under $500 \mathrm{~m}$ in height mainly originate from eastern areas. However, air masses in the height of $1000 \mathrm{~m}$ primarily occur in the northwest (Fig. 4(d)). This was mainly caused by the geographical location of Jinzhong (west, north and east surrounded by mountains) and the dominant wind direction in autumn (westerly and easterly). Thus, the migration of air masses below the height of $500 \mathrm{~m}$ was blocked by mountains, 
then entered Jinzhong from the east to the southwest. The air masses of $1000 \mathrm{~m}$ height passed through the northwestern region and crossed the mountain into Jinzhong.

\section{WSIS}

Fig. 3 shows the mass WSIs concentrations in $\mathrm{PM}_{2.5}$. The concentrations of total ions ranged from 13 to $117 \mu \mathrm{g} \mathrm{m}^{-3}$, with a median of $37 \mu \mathrm{g} \mathrm{m}^{-3}$, which accounted for $31 \%$ of the $\mathrm{PM}_{2.5}$ concentrations. The ratio was basically consistent with those observed in studies conducted in Lanzhou (31\%) (Tan et al., 2017); the ratio was lower than that in Handan (45\%) (Meng et al., 2016) and Taiyuan (33\%) (He et al., 2017) and higher than Kunming (26\%) (Shi et al., 2016). SNAs were the primary components of WSIs, which accounted for $79 \%$ of the total ions and $25 \%$ of the $\mathrm{PM}_{2.5}$ concentrations. $\mathrm{SO}_{4}{ }^{2-}$ and $\mathrm{NH}_{4}{ }^{+}$were the highest in the anions and cations and accounted for $37 \%$ and $18 \%$ of the total WSIs, which align with the observations derived by $\mathrm{He}$ et al. in Taiyuan (He et al., 2017).

The WSIs concentration was higher in autumn $\left(78 \mu \mathrm{g} \mathrm{m}^{-3}\right)$ and winter $\left(44 \mu \mathrm{g} \mathrm{m}^{-3}\right)$ and was lower in summer $\left(30 \mu \mathrm{g} \mathrm{m}^{-3}\right)$ and spring $\left(21 \mu \mathrm{g} \mathrm{m}^{-3}\right)$, which accounted for $55 \%$ (autumn), $27 \%$ (winter), $40 \%$ (summer), and $10 \%$ (spring) of $\mathrm{PM}_{2.5}$ concentrations, respectively (Table 2). Many studies have shown that the concentration of ions was the lowest in summer and highest in winter (Zhang et al., 2015; Deng et al., 2016; $\mathrm{Xu}$ et al., 2017a). However, $\mathrm{SO}_{4}{ }^{2-}, \mathrm{NO}_{3}{ }^{-}, \mathrm{NH}_{4}{ }^{+}$, and $\mathrm{K}^{+}$increased rapidly during autumn and even exceeded the content reported during winter in the study period. $\mathrm{SO}_{4}{ }^{2-}$, $\mathrm{NO}_{3}{ }^{-}$, and $\mathrm{NH}_{4}{ }^{+}$were the main SNAs, whereas $\mathrm{K}^{+}$is the indicator of biomass burning in the fine particles. $\mathrm{SO}_{2}$ is primarily produced through fossil fuels combustion and can be oxidized into $\mathrm{SO}_{4}{ }^{2-}$ on the fine particles by heterogeneous or homogeneous reactions (Cheng et al., 2000). The fine mode $\mathrm{NO}_{3}{ }^{-}$was primarily attributed to the photo-oxidation reaction of $\mathrm{N}_{2} \mathrm{O}_{5}$ that was derived through fossil fuel combustion and was generated by the gas-to-particles conversion ( $\mathrm{Li}$ et al., 2014). Particulate ammonium is formed by the gas-phase reactions of acid precursors $\left(\mathrm{H}_{2} \mathrm{SO}_{4}\right.$, $\mathrm{HNO}_{3}$, and $\mathrm{HCl}$, etc.) with ammonia vapor $\left(\mathrm{NH}_{3}\right)(\mathrm{Ho}$ et al. 2003; Zhang et al., 2011). The formation process of these reaction products is affected by the air temperature and humidity (Zhang et al., 2011). Ammonium nitrate can be preferentially formed in areas with rich ammonia $\left(\mathrm{NH}_{3}\right)$ and $\mathrm{HNO}_{3}$ in lower ambient temperatures (Li et al., 2014). The atmospheric oxidation rates are considerably affected by physical parameters, such as high temperature, high solar radiation, and high levels of atmospheric oxidant $\left(\mathrm{O}_{3}, \mathrm{O}_{2}\right.$, $\mathrm{H}_{2} \mathrm{O}_{2}, \mathrm{OH}$ radical, etc.). Zong et al. (2016) demonstrated that the atmosphere oxidation processes during autumn are stronger than those observed during the other three seasons, which can serve to accelerate the related secondary aerosol formation processes). During autumn, the temperature and solar radiation are higher than those during winter and compared with that of summer, rainfall is decreased (Fig. 3), whereas the pollution precursor increases. Besides, the local stagnant weather, higher relative humidity and lower wind speed, can be conductive to the accumulation of pollutants in autumn (Fig. 3). Combined with the backward trajectory during autumn (Fig. 4(d)), the possibility of long-distance transport was excluded. Therefore, the highest concentration during fall may be related to pollution in local areas, such as secondary aerosols and biomass combustion sources (Contini et al., 2010).

\section{Chemical forms of WSIs}

Considering the chemical valence and concentrations of WSIs, $\mathrm{Cl}^{-}, \mathrm{NO}_{3}{ }^{-}, \mathrm{SO}_{4}{ }^{2-}, \mathrm{Na}^{+}, \mathrm{NH}_{4}{ }^{+}, \mathrm{K}^{+}, \mathrm{Mg}^{2+}$, and $\mathrm{Ca}^{2+}$ were used to calculate their chemical forms. The correlation coefficients of WSIs in fine and coarse particles are shown in Table 3.

In fine particles, strong correlations were noted among $\mathrm{SO}_{4}{ }^{2-}, \mathrm{NO}_{3}{ }^{-}, \mathrm{Cl}^{-}$, and $\mathrm{NH}_{4}{ }^{+}$during winter and among $\mathrm{SO}_{4}{ }^{2-}$, $\mathrm{NO}_{3}{ }^{-}$, and $\mathrm{K}^{+}$during autumn, thus indicating that $\mathrm{NH}_{4} \mathrm{NO}_{3}$ $\left(\mathrm{R}^{2}=0.71\right),\left(\mathrm{NH}_{4}\right)_{2} \mathrm{SO}_{4}\left(\mathrm{R}^{2}=0.97\right)$, and $\mathrm{NH}_{4} \mathrm{Cl}\left(\mathrm{R}^{2}=0.81\right)$ were the main compounds found during winter, and $\mathrm{KNO}_{3}$ $\left(\mathrm{R}^{2}=0.69\right)$ and $\mathrm{K}_{2} \mathrm{SO}_{4}\left(\mathrm{R}^{2}=0.69\right)$ were noted during autumn. The linear fits of the data were described as $\left[\mathrm{NH}_{4}{ }^{+}\right]=$ $1.55\left[\mathrm{SO}_{4}{ }^{2-}\right]+0.16,\left[\mathrm{NH}_{4}{ }^{+}\right]=0.95\left[\mathrm{SO}_{4}{ }^{2-}+\mathrm{NO}_{3}{ }^{-}\right]+0.09$, $\left[\mathrm{NH}_{4}{ }^{+}\right]=0.87\left[\mathrm{SO}_{4}{ }^{2-}+\mathrm{NO}_{3}{ }^{-}+\mathrm{Cl}^{-}\right]-0.06$ (Fig. S1), which imply that $\left(\mathrm{NH}_{4}\right)_{2} \mathrm{SO}_{4}$ is the main chemical form. The equivalent ratio of $\mathrm{NH}_{4}{ }^{+}$and $\mathrm{SO}_{4}{ }^{2-}$ in the compound of $\mathrm{NH}_{4} \mathrm{HSO}_{4}$ and $\left(\mathrm{NH}_{4}\right)_{2} \mathrm{SO}_{4}$ were 0.5 and 1 , respectively. The slope of the regression equation between $\mathrm{NH}_{4}{ }^{+}$and $\left[\mathrm{SO}_{4}{ }^{2-}+\right.$ $\mathrm{NO}_{3}{ }^{-}$] was 0.95 ; however, the ratio was reduced to 0.87 when $\mathrm{Cl}^{-}$was included, thus indicating that the $\mathrm{NH}_{3}$ concentration

Table 2. Mass concentrations of water-soluble ions in $\mathrm{PM}_{2.5}$ in different seasons $\left(\mu \mathrm{g} \mathrm{m}^{-3}\right)$.

\begin{tabular}{llllll}
\hline Component & Winter & Spring & Summer & Autumn & Annual \\
\hline $\mathrm{F}^{-}$ & $0.21 \pm 0.07$ & $0.18 \pm 0.08$ & $0.14 \pm 0.09$ & $0.07 \pm 0.02$ & $0.15 \pm 0.09$ \\
$\mathrm{Cl}^{-}$ & $5 \pm 2$ & $0.96 \pm 0.68$ & $0.16 \pm 0.09$ & $2 \pm 1$ & $2 \pm 2$ \\
$\mathrm{NO}_{3}{ }^{-}$ & $15 \pm 11$ & $5 \pm 3$ & $3 \pm 2$ & $19 \pm 10$ & $11 \pm 10$ \\
$\mathrm{SO}_{4}^{2-}$ & $19 \pm 12$ & $8 \pm 5$ & $17 \pm 6$ & $25 \pm 6$ & $17 \pm 10$ \\
$\mathrm{Na}^{+}$ & $0.84 \pm 0.24$ & $0.55 \pm 1.1$ & $0.11 \pm 0.13$ & $0.27 \pm 0.16$ & $0.45 \pm 0.61$ \\
$\mathrm{NH}_{4}{ }^{+}$ & $9 \pm 5$ & $2 \pm 2$ & $5 \pm 2.5$ & $16 \pm 6$ & $8 \pm 7$ \\
$\mathrm{~K}^{+}$ & $0.64 \pm 0.22$ & $0.27 \pm 0.3$ & $0.31 \pm 0.21$ & $0.69 \pm 0.15$ & $0.48 \pm 0.29$ \\
$\mathrm{Mg}^{2+}$ & $0.2 \pm 0.07$ & $0.25 \pm 0.16$ & $0.19 \pm 0.06$ & $0.16 \pm 0.03$ & $0.2 \pm 0.09$ \\
$\mathrm{Ca}^{2+}$ & $4 \pm 2$ & $6 \pm 3$ & $5 \pm 2$ & $3 \pm 1$ & $4 \pm 2$ \\
Sum (Ions) & 44 & 21 & 30 & 78 & 37 \\
Percent & $27 \%$ & $10 \%$ & $40 \%$ & $55 \%$ & $31 \%$ \\
\hline Sum & & & & \\
\hline
\end{tabular}

Sum of ions divided by concentration of $\mathrm{PM}_{2.5}$. 
Table 3. Correlation coefficients between selected ions.

\begin{tabular}{|c|c|c|c|c|c|c|c|c|c|c|c|}
\hline & \multicolumn{5}{|c|}{ Fine particles } & \multicolumn{5}{|c|}{ Coarse particles } \\
\hline & & $\mathrm{NH}_{4}^{+}$ & $\mathrm{K}^{+}$ & $\mathrm{Mg}^{2+}$ & $\mathrm{Ca}^{2+}$ & $\mathrm{Na}^{+}$ & $\mathrm{NH}_{4}^{+}$ & $\mathrm{K}^{+}$ & $\mathrm{Mg}^{2+}$ & $\mathrm{Ca}^{2+}$ & $\mathrm{Na}^{+}$ \\
\hline \multirow[t]{3}{*}{ Winter } & $\mathrm{Cl}^{-}$ & 0.81 & 0.49 & -0.10 & 0.00 & -0.01 & -0.12 & 0.58 & 0.33 & 0.43 & 0.77 \\
\hline & $\mathrm{NO}_{3}^{-}$ & 0.71 & 0.30 & 0.19 & 0.03 & -0.08 & 0.91 & 0.61 & 0.27 & 0.66 & -0.42 \\
\hline & $\mathrm{SO}_{4}^{2-}$ & 0.97 & 0.47 & 0.00 & -0.11 & 0.03 & 0.79 & 0.60 & 0.93 & 0.96 & -0.24 \\
\hline \multirow[t]{3}{*}{ Spring } & $\mathrm{Cl}^{-}$ & -0.02 & -0.12 & -0.05 & -0.07 & -0.05 & 0.11 & -0.41 & 0.53 & -0.49 & 0.88 \\
\hline & $\mathrm{NO}_{3}^{-}$ & 0.27 & -0.11 & -0.06 & 0.01 & 0.02 & -0.26 & 0.92 & -0.27 & -0.25 & -0.27 \\
\hline & $\mathrm{SO}_{4}{ }^{2-}$ & -0.07 & -0.11 & 0.02 & 0.33 & 0.53 & 0.28 & -0.50 & -0.34 & -0.15 & 0.05 \\
\hline \multirow[t]{3}{*}{ Summer } & $\mathrm{Cl}^{-}$ & -0.12 & 0.03 & -0.01 & 0.10 & 0.32 & -0.31 & -0.23 & 0.62 & -0.50 & --- \\
\hline & $\mathrm{NO}_{3}^{-}$ & -0.13 & -0.12 & 0.35 & -0.08 & -0.12 & 0.27 & -0.14 & 0.81 & -0.37 & --- \\
\hline & $\mathrm{SO}_{4}{ }^{2-}$ & 0.28 & 0.03 & 0.13 & 0.17 & -0.13 & -0.09 & -0.06 & 0.83 & -0.47 & --- \\
\hline \multirow[t]{3}{*}{ Autumn } & $\mathrm{Cl}^{-}$ & -0.13 & -0.11 & -0.11 & 0.40 & -0.01 & -0.21 & -0.01 & 0.15 & -0.50 & 0.01 \\
\hline & $\mathrm{NO}_{3}^{-}$ & 0.57 & 0.69 & -0.08 & -0.07 & -0.06 & 0.78 & -0.20 & -0.40 & -0.43 & 0.75 \\
\hline & $\mathrm{SO}_{4}^{2-}$ & 0.38 & 0.69 & -0.07 & -0.00 & -0.04 & 0.14 & -0.27 & -0.45 & 0.16 & 0.01 \\
\hline
\end{tabular}

was inadequate for fully neutralizing the $\mathrm{SO}_{4}{ }^{2-}$ and $\mathrm{NO}_{3}{ }^{-}$, and the excess of $\mathrm{SO}_{4}{ }^{2-}$ and $\mathrm{NO}_{3}{ }^{-}$may be combined with $\mathrm{K}^{+}$ in the form of $\mathrm{KNO}_{3}$ and $\mathrm{K}_{2} \mathrm{SO}_{4}$ because moderate correlations were noted among these ions (Table 3). Moreover, the slope of $\left[\mathrm{NH}_{4}^{+}\right] /\left[\mathrm{SO}_{4}{ }^{2-}+\mathrm{NO}_{3}{ }^{-}+\mathrm{Cl}^{-}\right]$was 0.87 , thus indicating that part of the $\mathrm{NH}_{4}{ }^{+}$can also be associated with $\mathrm{NO}_{3}{ }^{-}$and $\mathrm{Cl}^{-}$in the form of $\mathrm{NH}_{4} \mathrm{NO}_{3}$ and $\mathrm{NH}_{4} \mathrm{Cl}$. Wang et al. (2015) demonstrated that $\mathrm{NH}_{4}{ }^{+}$is primarily derived from $\mathrm{NH}_{3}$ in the air, through gas-phase and aqueous-phase reactions with acidic species $\left(\mathrm{H}_{2} \mathrm{SO}_{4}, \mathrm{HNO}_{3}\right.$, and $\mathrm{HCl}$, etc.) to form $\left(\mathrm{NH}_{4}\right)_{2} \mathrm{SO}_{4}$, $\mathrm{NH}_{4} \mathrm{NO}_{3}$, and $\mathrm{NH}_{4} \mathrm{Cl}$, which are primarily present in the fine particles. $\left(\mathrm{NH}_{4}\right)_{2} \mathrm{SO}_{4}$ is a preferentially formed ion and is the most stable, followed by $\mathrm{NH}_{4} \mathrm{NO}_{3} ; \mathrm{NH}_{4} \mathrm{Cl}$ is the most volatile ion and was formed last (Zhang et al., 2008). These findings were consistent with the chemical composition of WSIs that was observed in Beijing (Wang et al., 2005).

Compared with the correlations in the fine particles, strong correlations were noted between $\mathrm{NO}_{3}{ }^{-}$and $\mathrm{NH}_{4}{ }^{+}$, $\mathrm{SO}_{4}{ }^{2-}$ and $\mathrm{Mg}^{2+}$ and between $\mathrm{SO}_{4}{ }^{2-}$ and $\mathrm{Ca}^{2+}$ during winter and between $\mathrm{K}^{+}$and $\mathrm{NO}_{3}{ }^{-}$during spring, thereby suggesting that $\mathrm{NH}_{4} \mathrm{NO}_{3}\left(\mathrm{R}^{2}=0.91\right), \mathrm{MgSO}_{4}\left(\mathrm{R}^{2}=0.93\right), \mathrm{CaSO}_{4}\left(\mathrm{R}^{2}=\right.$ $0.96)$, and $\mathrm{KNO}_{3}\left(\mathrm{R}^{2}=0.92\right)$ primarily existed in the coarse particles. The linear regression equation is described as $\left[\mathrm{NH}_{4}{ }^{+}\right]=0.38\left[\mathrm{SO}_{4}{ }^{2-}+\mathrm{NO}_{3}{ }^{-}\right]+0.03,\left[\mathrm{NH}_{4}{ }^{+}+\mathrm{Mg}^{2+}+\mathrm{Ca}^{2+}\right]$ $=1.04\left[\mathrm{SO}_{4}{ }^{2-}+\mathrm{NO}_{3}{ }^{-}\right]+0.13$ (Fig. S2), thereby suggesting that $\mathrm{NH}_{3}$ was insufficient for completely neutralizing the $\mathrm{SO}_{4}{ }^{2-}$ and $\mathrm{NO}_{3}{ }^{-}$. The excess of $\mathrm{SO}_{4}{ }^{2-}$ and $\mathrm{NO}_{3}{ }^{-}$may be associated with $\mathrm{Mg}^{2+}$ and $\mathrm{Ca}^{2+}$, which occurred as a form of $\mathrm{MgSO}_{4}$ and $\mathrm{CaSO}_{4}$, and part of $\mathrm{NO}_{3}{ }^{-}$can also be associated with $\mathrm{K}^{+}$to form $\mathrm{KNO}_{3}$ because higher correlations exist on these ions. The sulfuric acid and nitric acid on mineral dust could be through the heterogeneous reaction to form the coarse sulfate and nitrate (Liu et al., 2017).

\section{Acidity-alkalinity Analysis of Particles}

The acidity-alkalinity analysis of the fine and coarse particles was evaluated using the $\mathrm{R}_{\mathrm{C} / \mathrm{A}}$ (cation and anion equivalence ratio) in this study (Tian et al., 2017). The mass concentrations $\left(\mu \mathrm{g} \mathrm{m}^{-3}\right)$ of the anions and cations were converted to mole concentrations $\left(\mu \mathrm{mol} \mathrm{m} \mathrm{m}^{-3}\right)$, and the calculation method is depicted in Eq. (1). The time series of $\mathrm{R}_{\mathrm{C} / \mathrm{A}}$ during the sampling period are shown in Fig. 5 .
$R_{C / A}=\frac{\mathrm{Na}^{+} / 23+\mathrm{NH}_{4}^{+} / 18+\mathrm{K}^{+} / 39+\mathrm{Mg}^{2+} / 12+\mathrm{Ca}^{2+} / 20}{\mathrm{~F}^{-} / 19+\mathrm{Cl}^{-} / 35.5+\mathrm{NO}_{3}^{-} / 62+\mathrm{SO}_{4}^{2-} / 48}$

During the sampling period, the median value of $R_{C / A}$ in coarse particles was 1.93 , and the $\mathrm{R}_{\mathrm{C} / \mathrm{A}}$ values of more than $94 \%$ samples were greater than 1.00 . The median value of $\mathrm{R}_{\mathrm{C} / \mathrm{A}}$ in $\mathrm{PM}_{2.5}$ concentrations was 1.17 , and the $\mathrm{R}_{\mathrm{C} / \mathrm{A}}$ values of more than $83 \%$ samples were greater than 1 . These values indicated that the fine and coarse particles in Jinzhong were alkaline or neutralized if other anions (e.g., $\mathrm{NO}_{2}{ }^{-}, \mathrm{CO}_{3}{ }^{2-}$, $\mathrm{HCO}_{3}^{-}$) and organic acids were included, and their acidity was negligible, which is consistent with the findings of Shen et al. (2009).

During spring, $\mathrm{R}_{\mathrm{C} / \mathrm{A}}$ reached 8.45 , and the alkalinity was the strongest. It was primarily connected with the sandstorm weather that occurred in spring. Dust is the primary source of $\mathrm{Mg}^{2+}$ and $\mathrm{Ca}^{2+}$, which indicates that alkaline ions were significantly increasing. During winter and autumn, the $\mathrm{R}_{\mathrm{C} / \mathrm{A}}$ value for $\mathrm{PM}_{2.5}$ remained relatively stable, with a median of 1.05 and 1.12 , exceeding 1 , which indicates that the particles are approximately similar to the weakly alkaline. This is primarily due to the low alkaline ion (e.g., $\mathrm{Mg}^{2+}, \mathrm{Ca}^{2+}$ ) caused by the freezing of the soil and the high acid ion $\mathrm{Cl}^{-}$ content caused by coal combustion (Liu et al., 2017). The median $\mathrm{R}_{\mathrm{C} / \mathrm{A}}$ value during spring reached the maximum, and the alkalinity was stronger than those of other seasons, which was primarily contributed by the significant increase in alkaline ions from sandstorms. During summer, $90 \%$ of the $\mathrm{PM}_{2.5}$ samples had an $\mathrm{R}_{\mathrm{C} / \mathrm{A}}$ of more than 1.00 , with a median of 1.39 , which can be attributed to the higher alkaline ion concentration and indicate that particles were alkaline because of the higher concentration of $\mathrm{NH}_{3}$ and mineral dust emissions (Liu et al., 2017).

\section{Ratio Analysis}

Fig. 6 shows the ratio distribution of WSIs in fine and coarse particles. Coal combustion during winter releases increased pollutants and causes the increase of coal-related ions, such as $\mathrm{Cl}^{-}$, thus resulting in the highest ratio of $\mathrm{Cl}^{-} / \mathrm{K}^{+}$ found during winter in both fine and coarse particles. Many 


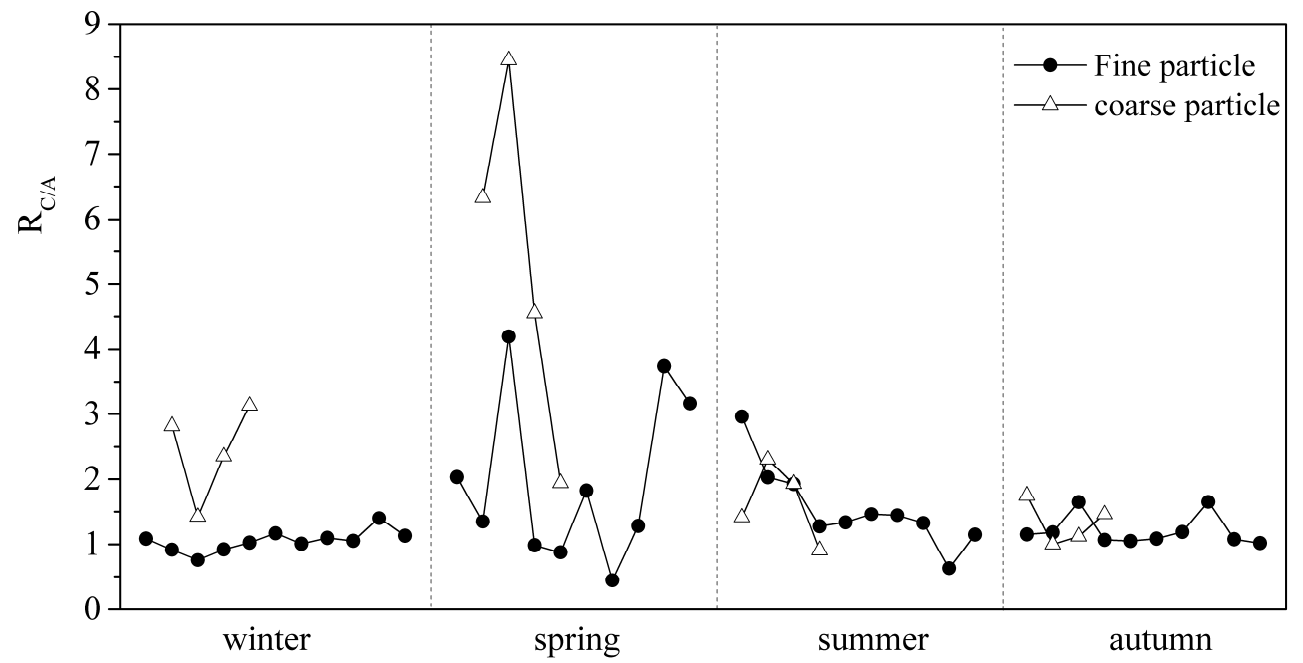

Fig. 5. $\mathrm{R}_{\mathrm{C} / \mathrm{A}}$ values in fine and coarse particles during different seasons.

(a)

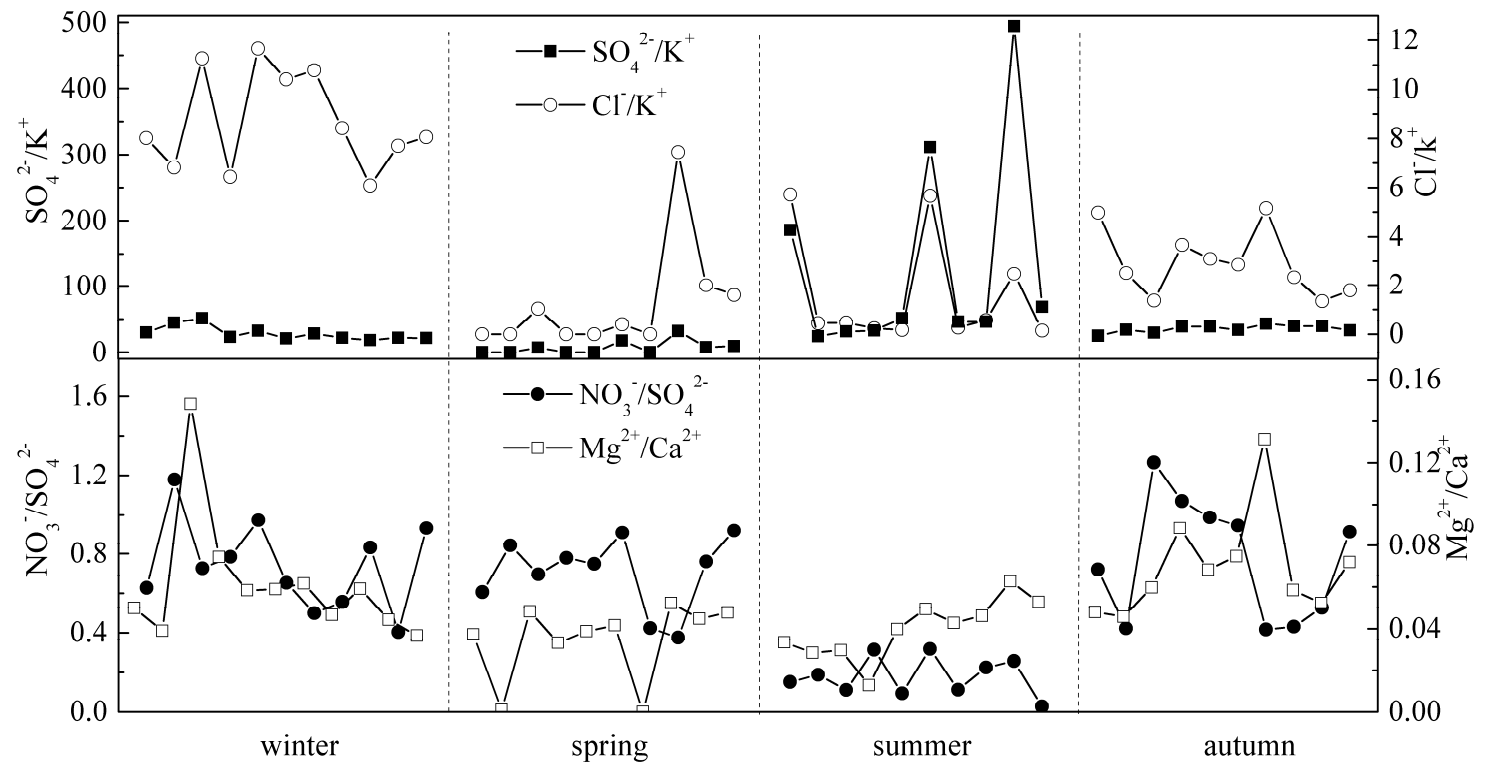

(b)

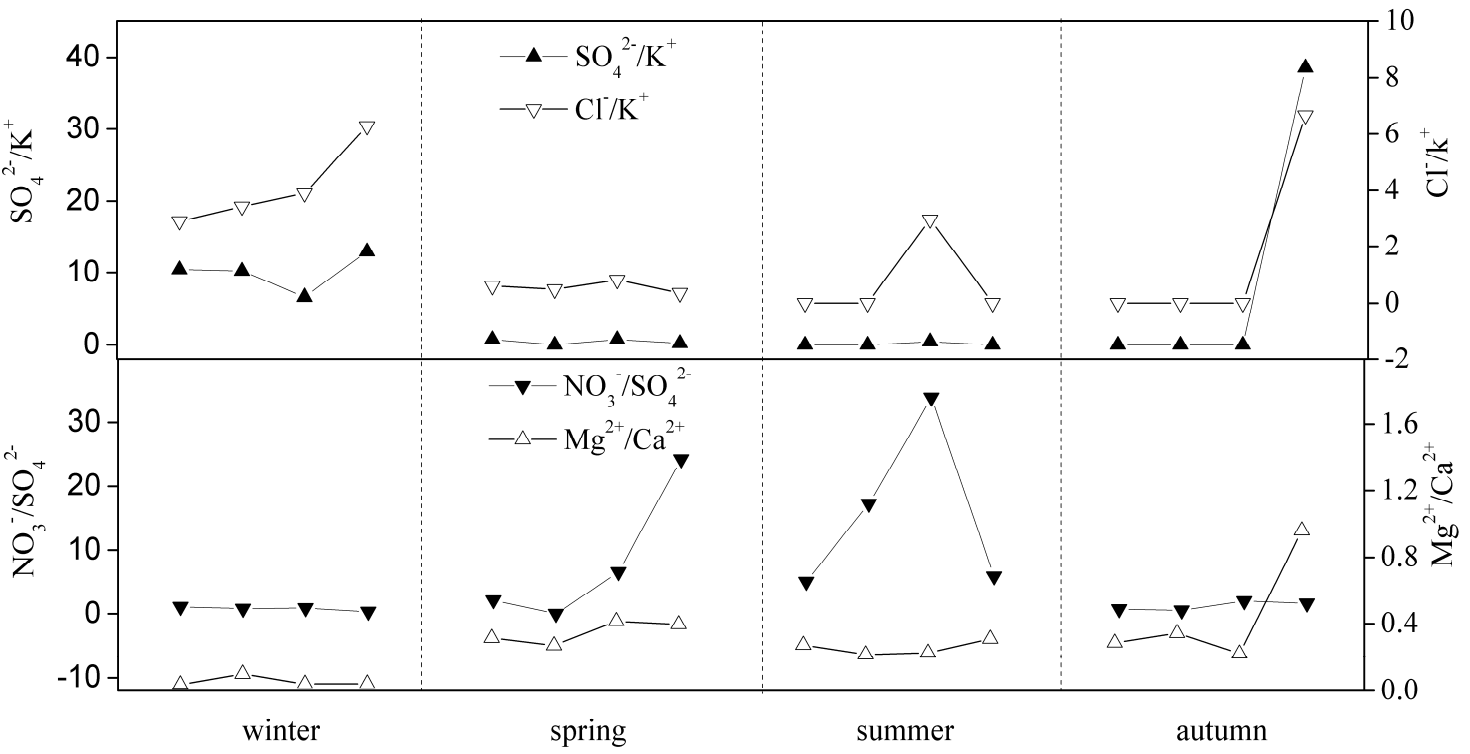

Fig. 6. Time series of $\mathrm{NO}_{3}{ }^{-} / \mathrm{SO}_{4}{ }^{2-}, \mathrm{Mg}^{2+} / \mathrm{Ca}^{2+}, \mathrm{SO}_{4}{ }^{2-} / \mathrm{K}^{+}$, and $\mathrm{Cl}^{-} / \mathrm{K}^{+}$ratios in (a) fine particles and (b) coarse particles. 
studies have suggested that $\mathrm{K}^{+}$in fine particles can often be used as an indicator of biomass burning (Fourtziou et al., 2016; Rajput et al., 2017). Unlike the seasonal characteristics of the $\mathrm{Cl}^{-} / \mathrm{K}^{+}$ratio, there was no obvious distinction for $\mathrm{Mg}^{2+} / \mathrm{Ca}^{2+}$ among the four seasons, and the median ratio in coarse particles was higher than that of fine particles.

The $\mathrm{NO}_{3}{ }^{-} / \mathrm{SO}_{4}{ }^{2-}$ mass ratio has been used as an indicator to evaluate the contribution to sulfate and nitrate from mobile versus stationary pollution sources (Xu et al., 2012; Wang et al., 2015b). The estimated ratios of $\mathrm{NO}_{\mathrm{x}}$ to $\mathrm{SO}_{\mathrm{x}}$ from vehicle exhausts are 8:1-13:1 compared with the estimated ratio of $\mathrm{NO}_{\mathrm{x}}$ to $\mathrm{SO}_{\mathrm{x}}$, which is $1: 2$, from coal combustion (Shen et al., 2008). The annual median of the $\mathrm{NO}_{3}{ }^{-} / \mathrm{SO}_{4}{ }^{2-}$ ratio in fine particles obtained in this study was 0.63 , which was lower than that of Beijing (1.12) (Wang et al., 2016b) and Hefei (1.10) (Deng et al., 2016), thus indicating that the contribution of stationary sources (e.g., coal) to fine particles in Jinzhong was increased in comparison to that of mobile sources (e.g., motor vehicles).

The seasonal median of the $\mathrm{NO}_{3}{ }^{-} / \mathrm{SO}_{4}{ }^{2-}$ ratio followed the order of autumn $(0.82)>$ spring $(0.75)>$ winter $(0.73)>$ summer (0.17) in fine particles, which is consistent with the findings of Wang et al. (2005). Significantly increased $\mathrm{NO}_{3}{ }^{-}$ $/ \mathrm{SO}_{4}{ }^{2-}$ ratios were observed during autumn, winter, and spring, compared with that during summer. High temperature could cause the decomposition of $\mathrm{NH}_{4} \mathrm{NO}_{3}$ into gaseous $\mathrm{HNO}_{3}$ and $\mathrm{NH}_{3}$, thereby reducing the $\mathrm{NO}_{3}{ }^{-}$concentration in fine particles (Li et al., 2014). Different from fine particles, the $\mathrm{NO}_{3}{ }^{-} / \mathrm{SO}_{4}{ }^{2-}$ ratio in coarse particles followed the order of summer $(11.56)>$ spring $(4.37)>$ autumn $(1.17)>$ winter (0.85), which is consistent with the findings of Shen et al. (2008). The increased concentrations of the coarse-mode $\mathrm{NO}_{3}{ }^{-}$may be explained by the heterogeneous reaction of the gas precursor on coarse particles that contain increased calcium and magnesium during summer (Li et al., 2014), thereby causing the increased $\mathrm{NO}_{3}{ }^{-} / \mathrm{SO}_{4}{ }^{2-}$ ratio in the coarse particles.

\section{Source Analysis of WSIs in Fine and Coarse Particles}

A principal component analysis (PCA) was conducted to further apportion the potential sources of WSIs in fine and coarse particles in this study. All the principal factors were extracted with the initial eigenvalue $>1.0$. The Kaiser-MeyerOlkin values in fine and coarse particles were above 0.6 , and the PCA result for WSIs is shown in Tables 4 and 5.

Table 4 shows that the WSIs in $\mathrm{PM}_{2.5}$ aerosol samples comprises three PCA factors, thus accounting for approximately $80 \%$ of the total variance in the concentration data. Factor 1 accounts for $44 \%$ of the total variance and is strongly loaded with $\mathrm{NH}_{4}{ }^{+}(0.92), \mathrm{SO}_{4}{ }^{2-}(0.89), \mathrm{NO}_{3}{ }^{-}(0.88)$, and $\mathrm{K}^{+}(0.75)$, thereby indicating that it potentially originated from the secondary source aerosol and anthropogenic sources, particularly coal combustion and biomass burning (Wang et al., 2015a). The formation of $\mathrm{SO}_{4}{ }^{2-}$ and $\mathrm{NO}_{3}{ }^{-}$in the fine particles were primarily associated with the secondary pollutants transformed from $\mathrm{SO}_{2}$ and $\mathrm{NO}_{3}$ by using photochemical oxidation (Zhao et al., 2011). Factor 2, which accounts for $20 \%$ of the variance, is primarily affected by $\mathrm{Mg}^{2+}$ and $\mathrm{Ca}^{2+}$, with an obvious loading of 0.85 and 0.66 , respectively. $\mathrm{Mg}^{2+}$ and $\mathrm{Ca}^{2+}$ were considered as traces of dust particles from construction sites and roads (Zhang et al., 2011; Meng et al., 2016). Factor 3 is loaded with $\mathrm{Na}^{+}(0.69)$ and $\mathrm{F}^{-}(0.65)$, and it accounts for $16 \%$ of the total variance, thereby suggesting that the potential source is industrial emissions (Wang et al., 2015a).

Table 5 presents three PCA factors of WSIs in coarse particles, thereby accounting for approximately $79 \%$ of the total variance, and $\mathrm{Al}$ as a tracer for soil dust particles was also included as input data. Factor 1, which accounts for $31 \%$ of the variance, is heavily loaded by $\mathrm{K}^{+}(0.91)$ and $\mathrm{Na}^{+}(0.82)$, which can indicate the potential source from coal combustion and biomass burning. Factor 2 is loaded with $\mathrm{Ca}^{2+}(0.76)$, $\mathrm{Mg}^{2+}(0.64)$, and $\mathrm{Al}(0.63)$ and accounts for $26 \%$ of the total variance, thereby suggesting that the dust originates from soil particles and falling dust. Factor 3 accounts for $22 \%$ of the total variance and is dominated by $\mathrm{SO}_{4}{ }^{2-}(0.92), \mathrm{NH}_{4}{ }^{+}$ $(0.65)$, and $\mathrm{NO}_{3}{ }^{-}(0.52)$, thereby indicating that it potentially originates from a secondary reaction. The PCA source analysis of components on the coarse particles was consistent with the findings of Wang et al. (2015a). The coarse sulfate

Table 4. Result of principal component analysis for water-soluble ions in the fine particles.

\begin{tabular}{llll}
\hline \multirow{2}{*}{ Ion } & \multicolumn{2}{c}{ PCA source } \\
\cline { 2 - 4 } & PC1 & PC2 & PC3 \\
\hline $\mathrm{F}^{-}$ & -0.33 & 0.45 & $\mathbf{0 . 6 5}$ \\
$\mathrm{Cl}^{-}$ & 0.59 & 0.37 & 0.57 \\
$\mathrm{NO}_{3}{ }^{-}$ & $\mathbf{0 . 8 8}$ & 0.20 & -0.06 \\
$\mathrm{SO}_{4}{ }^{2-}$ & $\mathbf{0 . 8 9}$ & -0.03 & 0.15 \\
$\mathrm{Na}^{+}$ & 0.26 & -0.09 & $\mathbf{0 . 6 9}$ \\
$\mathrm{NH}_{4}{ }^{+}$ & $\mathbf{0 . 9 2}$ & 0.07 & -0.23 \\
$\mathrm{~K}^{+}$ & $\mathbf{0 . 7 5}$ & 0.49 & -0.14 \\
$\mathrm{Ca}^{2+}$ & -0.26 & $\mathbf{0 . 8 5}$ & -0.24 \\
$\mathrm{Mg}^{2+}$ & -0.62 & $\mathbf{0 . 6 6}$ & -0.22 \\
Variance & 44 & 20 & 16 \\
$\mathrm{Cumulative}_{\text {Source }}$ & 44 & 64 & 80 \\
& Secondary source & Dust source & Industrial emission \\
& Coal combustion & & \\
\hline
\end{tabular}


Table 5. Result of principal component analysis for water-soluble ions in the coarse particles.

\begin{tabular}{llll}
\hline \multirow{2}{*}{ Ion } & \multicolumn{2}{c}{ PCA source } \\
\cline { 2 - 4 } & PC1 & PC2 & PC3 \\
\hline $\mathrm{F}^{-}$ & -0.58 & -0.30 & -0.45 \\
$\mathrm{Cl}^{-}$ & 0.53 & -0.78 & -0.07 \\
$\mathrm{NO}_{3}{ }^{-}$ & -0.28 & -0.07 & $\mathbf{0 . 5 2}$ \\
$\mathrm{SO}_{4}{ }^{-}$ & -0.28 & -0.14 & $\mathbf{0 . 9 2}$ \\
$\mathrm{Na}^{+}$ & $\mathbf{0 . 8 2}$ & -0.43 & -0.08 \\
$\mathrm{NH}_{4}{ }^{+}$ & 0.51 & 0.51 & $\mathbf{0 . 6 5}$ \\
$\mathrm{K}^{+}$ & $\mathbf{0 . 9 1}$ & 0.15 & -0.23 \\
$\mathrm{Ca}^{2+}$ & 0.07 & $\mathbf{0 . 7 6}$ & 0.18 \\
$\mathrm{Mg}^{2+}$ & -0.45 & $\mathbf{0 . 6 4}$ & -0.53 \\
$\mathrm{Al}$ & 0.59 & $\mathbf{0 . 6 3}$ & -0.24 \\
Variance & 31 & 26 & 22 \\
$\mathrm{Cumulative}$ & 31 & 57 & 79 \\
Source & Biomass burning & Dust source & Secondary reaction \\
& Coal combustion & & \\
\hline
\end{tabular}

and nitrate were primarily attributed to the reaction with crustal species in the coarse particles or through the heterogeneous reaction of precursor gases with crustal particles (Anlauf et al., 2006).

\section{CONCLUSION}

The $\mathrm{PM}_{2.5}$ concentrations ranged from 45 to $326 \mu \mathrm{g} \mathrm{m}^{-3}$, with a median of $133 \mu \mathrm{g} \mathrm{m}^{-3}$, which significantly exceeded the daily concentration limitation value of $35 \mu \mathrm{g} \mathrm{m}^{-3}$ that was issued by the US EPA and $75 \mu \mathrm{g} \mathrm{m}^{-3}$ that was issued by Chinese NAAQS and MEP (Ministry of Environmental Protection of the People's Republic of China). The proportion of ions distributed in fine particles was the highest, thereby accounting for $75 \%$ of the total ions in TSP. The seasonal variations of WSIs followed the order of spring $<$ summer $<$ winter $<$ autumn, thereby indicating that the different characteristics of the four seasons was a crucial factor that affected the WSIs distributions. The ions $\left(\mathrm{NH}_{4}{ }^{+}, \mathrm{K}^{+}, \mathrm{NO}_{3}{ }^{-}\right.$, and $\mathrm{SO}_{4}{ }^{2-}$ ) primarily existed in the form of $\mathrm{NH}_{4} \mathrm{NO}_{3}$, $\left(\mathrm{NH}_{4}\right)_{2} \mathrm{SO}_{4}$ and $\mathrm{K}_{2} \mathrm{SO}_{4}$ in fine particles, and $\mathrm{Ca}^{2+}$ and $\mathrm{Mg}^{2+}$ were primarily concentrated in the form of $\mathrm{MgSO}_{4}$ and $\mathrm{CaSO}_{4}$ in coarse particles, thereby suggesting that the fine and coarse particles in Jinzhong were alkaline during the study period. The result of the ratio analysis showed that the highest ratio of $\mathrm{Cl}^{-} / \mathrm{K}^{+}$was observed during winter in both fine and coarse particles; however, there was no obvious distinction for $\mathrm{Mg}^{2+} / \mathrm{Ca}^{2+}$ among the four seasons. The $\mathrm{NO}_{3}{ }^{-}$ $/ \mathrm{SO}_{4}{ }^{2-}$ ratio in coarse particles was significantly higher than that in fine particles, particularly in summer, thus indicating that the heterogeneous reaction on particles plays a vital role in the formation of $\mathrm{NO}_{3}{ }^{-}$in coarse particles. The result of the PCA showed that the source of WSIs was in Jinzhong secondary source aerosol, dust particles, coal combustion, biomass burning and industrial emission. The coal combustion and biomass burning have been considered as the leading emission sources to be controlled for improving air quality. The government can promote to use clean energy and accelerate the achievement of a high economic value of biomass, which will significantly improve air quality in Jinzhong.

\section{ACKNOWLEDGEMENTS}

This study was funded by the National Natural Science Foundation of China (41502324), Shanxi Province Science Foundation for Youths (2015021170), Science and Technology Innovation Projects of Higher School (2015136), and the School Foundation of Taiyuan University of Technology (2013Z053).

\section{SUPPLEMENTARY MATERIAL}

Supplementary data associated with this article can be found in the online version at http://www.aaqr.org.

\section{REFERENCES}

Anlauf, K., Li, S.M., Leaitch, R., Brook, J., Hayden, K., Toom-Sauntry, D. and Wiebe, A. (2006). Ionic composition and size characteristics of particles in the Lower Fraser Valley: Pacific 2001 field study. Atmos. Environ. 40: 2662-2675.

Chen, Y.Z. (2010). The study of the seasonal variation characteristic of the atmospheric aerosol and its chemical composition in Guiyang City. Ph.D Thesis, Nanchang University, China. (in Chinese)

Cheng, Z.L., Lam, K.S., Chan, L.Y., Wang, T. and Cheng, K.K. (2000). Chemical characteristics of aerosols at coastal station in Hong Kong. I. Seasonal variation of major ions, halogens and mineral dusts between 1995 and 1996. Atmos. Environ. 34: 2771-2783.

Contini, D., Genga, A., Cesari, D., Siciliano, M., Donateo, A., Bove, M.C. and Guascito, M.R. (2010). Characterisation and source apportionment of $\mathrm{PM}_{10}$ in an urban background site in Lecce. Atmos. Res. 95: 40-54.

de Kok, T.M.C.M., Driece, H.A.L., Hogervorst, J.G.F. and Briedé, J.J. (2006). Toxicological assessment of ambient and traffic-related particulate matter: A review of recent studies. Mutat. Res. Rev. Mutat. Res. 613: 103-122.

Deng, X.L., Shi, C.E., Wu, B.W., Yang, Y.J., Jin, Q., Wang, H.L., Zhu, S. and Yu, C. (2016). Characteristics of the 
water-soluble components of aerosol particles in Hefei, China. J. Environ. Sci. 42: 32-40.

Fourtziou, L., Liakakou, E., Stavroulas, I., Theodosi, C., Zarbas, P., Psiloglou, B., Sciare, J., Maggos, T., Bairachtari, K. and Bougiatioti, A. (2016). Multi-tracer approach to characterize domestic wood burning in Athens (Greece) during wintertime. Atmos. Environ. 148: 89-101.

Han, X. (2007). Retrieval of Lanzhou urban and suburb aerosol radiative properties using lidar measurement. Ph.D Thesis, Lanzhou University, China. (in Chinese)

He, L., Chen, H., Rangognio, J., Yahyaoui, A., Colin, P., Wang, J., Daële, V. and Mellouki, A. (2018). Fine particles at a background site in central France: Chemical compositions, seasonal variations and pollution events. Sci. Total Environ. 612: 1159-1170.

He, Q., Yan, Y., Guo, L., Zhang, Y., Zhang, G. and Wang, X. (2017). Characterization and source analysis of watersoluble inorganic ionic species in $\mathrm{PM}_{2.5}$ in Taiyuan City, China. Atmos. Res. 184,48-55

Huebert, B.J., Wang, M.X. and Wei-Xiu, L.Ü. (1988). Atmospheric nitrate, sulfate, smmonium and calcium concentrations in China. Tellus B 40: 260-269.

Khan, M.B., Masiol, M., Formenton, G., Di, A.G., De, G.G., Agostinelli, C. and Pavoni, B. (2016). Carbonaceous $\mathrm{PM}_{2.5}$ and secondary organic aerosol across the Veneto Region (Ne Italy). Sci. Total Environ. 542: 172-181.

Koracin, D., Vellore, R., Lowenthal, D.H., Watson, J.G., Koracin, J., McCord, T., DuBois, D.W., Chen, L.W.A., Kumar, N., Knipping, E.M., Wheeler, N.J.M., Craig, K. and Reid, S. (2011). Regional source identification using Lagrangian stochastic particle dispersion and HYSPLIT backward-trajectory models. J. Air Waste Manage. Assoc. 61: 660-672.

Kumar, P., Kumar, S. and Yadav, S. (2017). Seasonal variations in size distribution, water-soluble ions, andcarbon content of size-segregated aerosols over New Delhi. Environ. Sci. Pollut. Res. 25: 6061.

Li, L., Yin, Y., Kong, S., Wen, B., Chen, K., Yuan, L. and Li, Q. (2014). Altitudinal effect to the size distribution of water soluble inorganic ions in PM at Huangshan, China. Atmos. Environ. 98: 242-252.

Li, X., Wang, L., Ji, D., Wen, T., Pan, Y., Sun, Y. and Wang, Y. (2013). Characterization of the size-segregated watersoluble inorganic ions in the Jing-Jin-Ji urban agglomeration: Spatial/temporal variability, size distribution and sources. Atmos. Environ. 77: 250-259.

Liu, Z., Xie, Y., Hu, B., Wen, T., Xin, J., Li, X. and Wang, Y. (2017). Size-resolved aerosol water-soluble ions during the summer and winter seasons in Beijing: Formation mechanisms of secondary inorganic aerosols. Chemosphere 183: 119-131.

Meng, C.C., Wang, L.T., Zhang, F.F., Wei, Z., Ma, S.M., Ma, $X$. and Yang, J. (2016). Characteristics of concentrations and water-soluble inorganic ions in $\mathrm{PM}_{2.5}$ in Handan city, Hebei Province, China. Atmos. Res. 171: 133-146.

Meng, Z.Y., Jiang, X.M., Yan, P., Lin, W.L., Zhang, H.D. and Wang, Y. (2007). Characteristics and sources of $\mathrm{PM}_{2.5}$ and carbonaceous species during winter in Taiyuan, China.
Atmos. Environ. 41: 6901-6908.

Osunsanya, T., Prescott, G. and Seaton, A. (2001). Acute respiratory effects of particles: Mass or number. Occup. Environ. Med. 58: 154-159.

Rajput, P., Singh, D.K., Singh, A.K. and Gupta, T. (2017). Chemical composition and source-apportionment of submicron particles during wintertime over northern India: New insights on influence of fog-processing. Environ. Pollut. 233: 81-91.

Shakya, K.M., Peltier, R.E., Shrestha, H. and Byanju, R.M. (2017). Measurements of TSP, $\mathrm{PM}_{10}, \mathrm{PM}_{2.5}, \mathrm{BC}$ and PM chemical composition from an urban residential location in Nepal. Atmos. Pollut. Res. S1309104216305955.

Shen, Z., Arimoto, R., Cao, J., Zhang, R., Li, X., Du, N., Okuda, T., Nakao, S. and Tanaka, S. (2008). Seasonal variations and evidence for the effectiveness of pollution controls on water-soluble inorganic species in total suspended particulates and fine particulate matter from Xi'an, China. J. Air Waste Manage. Assoc. 58: 15601570 .

Shen, Z., Cao, J., Arimoto, R., Han, Z., Zhang, R., Han, Y., Liu, S., Okuda, T., Nakao, S. and Tanaka, S. (2009). Ionic composition of TSP and $\mathrm{PM}_{2.5}$ during dust storms and air pollution episodes at Xi'an, China. Atmos. Environ. 43: 2911-2918.

Shi, J., Ding, X., Zhou, Y., You, R., Huang, L., Hao, J., Xiang, F., Yang, J., Shi, Z. and Han, X. (2016). Characteristics of chemical components in $\mathrm{PM}_{2.5}$ at a plateau city, Southwest China. Front. Environ. Sci. Eng. 10: 5.

Tan, J, Duan, J., Zhen, N., He, K., and Hao, J. (2015). Chemical characteristics and source of size-fractionated atmospheric particle in haze episode in Beijing. Atmos. Res. 167: 24-33.

Tan, J., Zhang, L., Zhou, X., Duan, J., Li, Y., Hu, J. and He, K. (2017). Chemical characteristics and source apportionment of $\mathrm{PM}_{2.5}$ in Lanzhou, China. Sci. Total Environ. 601-602: 1743-1752.

Tao, J., Ho, K.F., Chen, L., Zhu, L., Han, J. and Xu, Z. (2009). Effect of chemical composition of $\mathrm{PM}_{2.5}$ on visibility in Guangzhou, China, 2007 spring. China Particuology 7: 68-75.

Tao, J., Zhang, L., Engling, G., Zhang, R., Yang, Y., Cao, J., Zhu, C., Wang, Q. and Luo, L. (2013). Chemical composition of $\mathrm{PM}_{2.5}$ in an urban environment in Chengdu, China: Importance of springtime dust storms and biomass burning. Atmos. Res. 122: 270-283.

Tian, S., Pan, Y. and Wang, Y. (2017). Ion balance and acidity of size-segregated particles during haze episodes in urban Beijing. Atmos. Res. 201: 159-167.

Wang, H., Zhu, B., Shen, L., Xu, H., An, J., Xue, G. and Cao, J. (2015a). Water-soluble ions in atmospheric aerosols measured in five sites in the Yangtze River Delta, China: size-fractionated, seasonal variations and sources. Atmos. Environ. 123: 370-379.

Wang, J., Zhou, M., Liu, B.S., Wu, J.H., Peng, X., Zhang, Y.F., Han, S.Q., Feng, Y.C. and Zhu, T. (2016a). Characterization and source apportionment of sizesegregated atmospheric particulate matter collected at ground level and from the urban canopy in Tianjin. 
Environ. Pollut. 219: 982-992.

Wang, P., Cao, J.J., Shen, Z.X., Han, Y.M., Lee, S.C., Huang, Y., Zhu, C.S., Wang, Q.Y., Xu, H.M. and Huang, R.J. (2015b). Spatial and seasonal variations of $\mathrm{PM}_{2.5}$ mass and species during 2010 in Xi'an, China. Sci. Total Environ. 508: 477-487.

Wang, Y., Zhuang, G., Tang, A., Yuan, H., Sun, Y., Chen, S. and Zheng, A. (2005). The ion chemistry and the source of $\mathrm{PM}_{2.5}$ aerosol in Beijing. Atmos. Environ. 39: 37713784.

Wang, Z., Zhang, D., Liu, B., Li, Y., Chen, T., Sun, F., Yang, D., Liang, Y., Chang, M. and Yang, L. (2016b). Analysis of chemical characteristics of $\mathrm{PM}_{2.5}$ in Beijing over a 1-year period. J. Atmos. Chem. 73: 407-425.

Wu, D., Shen, K.Y., Gai, X.L, Xia, J.R., Liu, G., Li, F.Y. and Yang, M. (2017). Characteristics of water-soluble organic carbon (WSOC) in atmospheric particulate matter at northern suburb of Nanjing. China Environ. Sci. 37: 3237-3246.

Xia, Y., Tao, J., Zhang, L., Zhang, R., Li, S., Wu, Y., Cao, J., Wang, X., Ma, Q. and Zhe, X. (2017). Impact of size distributions of major chemical components in fine particles on light extinction in urban Guangzhou. Sci. Total Environ. 587-588: 240-247.

Xing, J., Cui, K., Tang, H., Lee, W.J., Wang, L.C., Zhu, J. and Huang, Q. (2017). Part II: $\mathrm{PM}_{2.5}$ and polychlorinated dibenzo-p-dioxins and dibenzofurans (PCDD/Fs) in the ambient air of northern China. Aerosol Air Qual. Res. 17: 2010-2026.

Xiu, G., Zhang, D., Chen, J., Huang, X., Chen, Z.., Guo, H. and Pan, J. (2004). Characterization of major watersoluble inorganic ions in size-fractionated particulate matters in shanghai campus ambient air. Atmos. Environ. 38: 227-236.

Xu, D., Wang, Z., Lv, Y., Teng, E., Zhang, L. and Wang, C. (2014). Chemical characteristics of water-soluble ions in particulate matter in three metropolitan areas in the north China plain. PLoS One 9:12.

Xu, J.S., Xu, M.X., Snape, C., He, J., Behera, S.N., Xu, H.H., Ji, D.S., Wang, C.J., Yu, H. and Xiao, H. (2017a). Temporal and spatial variation in major ion chemistry and source identification of secondary inorganic aerosols in northern Zhejiang Province, China. Chemosphere 179: 316-330.

Xu, L., Chen, X., Chen, J., Zhang, F., He, C., Zhao, J. and Yin, L. (2012). Seasonal variations and chemical compositions of $\mathrm{PM}_{2.5}$ aerosol in the urban area of Fuzhou, China. Atmos. Res. 104: 264--272.

Xu, L., Duan, F., He, K., Ma, Y., Zhu, L., Zheng, Y., Huang, T., Kimoto, T., Ma, T. and Li, H. (2017b). Characteristics of the secondary water-soluble ions in a typical autumn haze in Beijing. Environ. Pollut. 227: 296-305.
Yang, Y., Zhou, R., Wu, J., Yu, Y., Ma, Z., Zhang, L. and Di, Y.A. (2015). Seasonal variations and size distributions of water-soluble ions in atmospheric aerosols in Beijing, 2012. J. Environ. Sci. 34: 197-205.

Yao, X., Lau, A.P.S., Ming, F., Chan, C.K. and Min, H. (2003). Size distributions and formation of ionic species in atmospheric particulate pollutants in Beijing, China: 1-inorganic ions. Atmos. Environ. 37: 2991-3000.

Yu, X., Ma, J., An, J., Yuan, L., Zhu, B., Liu, D., Wang, J., Yang, Y. and Cui, H. (2016). Impacts of meteorological condition and aerosol chemical compositions on visibility impairment in Nanjing, China. J. Clean Prod. 131: 112120.

Zhai, S., An, X., Zhao, T., Sun, Z., Wang, W., Hou, Q., Guo, Z. and Wang, C. (2018). Detection of critical $\mathrm{PM}_{2.5}$ emission sources and their contributions to a heavy haze episode in Beijing, China, using an adjoint model. Atmos. Chem. Phys. 18: 6241-6258.

Zhang, F., Wang, Z.W., Cheng, H.R., Lv, X.P., Gong, W., Wang, X.M. and Zhang, G. (2015). Seasonal variations and chemical characteristics of $\mathrm{PM}_{2.5}$ in Wuhan, central China. Sci. Total Environ. 518-519: 97-105.

Zhang, L., Vet, R., Wiebe, A., Mihele, C., Sukloff, B., Chan, E., Moran, M.D. and Iqbal, S. (2008). Characterization of the size-segregated water-soluble inorganic ions at eight Canadian rural sites. Atmos. Chem. Phys. 8: 7133-7151.

Zhang, T., Cao, J.J., Tie, X.X., Shen, Z.X., Liu, S.X., Ding, H., Han, Y.M., Wang, G.H., Ho, K.F., Qiang, J. and Li, W.T. (2011). Water-soluble ions in atmospheric aerosols measured in Xi'an, China: Seasonal variations and sources. Atmos. Res. 102: 110-119.

Zhao, J., Zhang, F., Xu, Y. and Chen, J. (2011). Characterization of water-soluble inorganic ions in sizesegregated aerosols in coastal city, Xiamen. Atmos. Res. 99: 546-562.

Zhao, S., Yu, Y., Yin, D., He, J., Liu, N., Qu, J. and Xiao, J. (2016). Annual and diurnal variations of gaseous and particulate pollutants in 31 provincial capital cities based on in situ air Quality monitoring data from China National Environmental Monitoring Center. Environ. Int. 86: 92106.

Zhou, C., Chen, J. and Wang, S. (1992). Examining the effects of socioeconomic development on fine particulate matter $\left(\mathrm{PM}_{2.5}\right)$ in China's cities using spatial regression and the geographical detector technique. Sci. Total Environ. 619-620: 436-445.

Received for review, March 10, 2019

Revised, June 11, 2019

Accepted, September 22, 2019 